\title{
Ligand-Controlled Regioselectivity in the Hydrothiolation of Alkynes by Rhodium N-Heterocyclic Carbene Catalysts
}

\author{
Andrea Di Giuseppe, ${ }^{\dagger, \dagger}$ Ricardo Castarlenas, ${ }^{*},{ }^{\dagger}$ Jesús J. Pérez-Torrente, ${ }^{\dagger}$ Marcello Crucianelli, ${ }^{\dagger}$ Victor \\ Polo, ${ }^{\S}$ Rodrigo Sancho, ${ }^{\dagger}$ Fernando J. Lahoz, ${ }^{\dagger}$ and Luis A. Oro ${ }^{\dagger}$ \\ ${ }^{\dagger}$ Instituto de Síntesis Química y Catálisis Homogénea (ISQCH)-Departamento de Química Inórganica, CSIC-Universidad de \\ Zaragoza, Pl. S. Francisco S/N 50009 Zaragoza, Spain \\ Dipartimento di Chimica, Ingegneria Chimica e Materiali, Università dell’Aquila. Via Vetoio, I-67100-Coppito (AQ), Italy \\ $\S$ Departamento de Química Física, Universidad de Zaragoza. Pl. S. Francisco S/N 50009 Zaragoza, Spain
}

KEYWORDS. Hydrothiolation, Migratory Insertion, N-Heterocyclic Carbene, Pyridine, Rhodium Catalyst.

ABSTRACT: Rh-N-heterocyclic carbene compounds $\left[\mathrm{Rh}\left(\mu \text {-Cl)(IPr) }\left(\eta^{2} \text {-olefin }\right)\right]_{2}\right.$ and $\mathrm{RhCl}(\operatorname{IPr})(\mathrm{py})\left(\eta^{2}\right.$-olefin $)(\operatorname{IPr}=1,3$-bis(2,6-diisopropylphenyl)imidazol-2-carbene, $\mathrm{py}=$ pyridine, olefin $=$ cyclooctene or ethylene $)$ are highly active catalysts for alkyne hydrothiolation under mild conditions. A regioselectivity switch from linear to 1-substituted vinyl sulfides was observed when mononuclear $\mathrm{RhCl}(\mathrm{IPr})(\mathrm{py})\left(\eta^{2}\right.$-olefin) catalysts were used instead of dinuclear precursors. A complex interplay between electronic and steric effects exerted by IPr, pyridine, and hydride ligands, accounts for the observed regioselectivity. Both IPr and pyridine ligands stabilize the formation of square-pyramidal thiolate-hydride active species, in which the encumbered and powerful electron donor IPr ligand directs the coordination of pyridine trans to it, consequently blocking the access of the incoming alkyne in this position. Simultaneously, the higher trans director hydride ligand paves the way to a cis thiolate-alkyne disposition, favoring the formation of 2,2-disubstituted metal-alkenyl species and subsequently the Markovnikov vinyl sulfides via alkenyl-hydride reductive elimination. DFT calculations support a plausible reaction pathway where the migratory insertion of the alkyne into the rhodiumthiolate bond is the rate-determining step.

\section{INTRODUCTION}

Hydrothiolation of carbon-carbon multiple bonds is a direct and atom economical method for the formation of carbonsulfur bonds present in many biologically active compounds. ${ }^{1}$ Among them, vinyl sulfides, in addition to their interesting biological properties, ${ }^{2}$ are also useful synthetic intermediates in organic transformations, ${ }^{3}$ ranging from enol substitutes, ${ }^{4}$ Diels-Alder, ${ }^{5}$ thio-Claisen, ${ }^{6}$ Michael acceptors, ${ }^{7}$ or olefin metathesis, ${ }^{8}$ among others. ${ }^{9}$ Several metal catalysts including $\mathrm{Mo},{ }^{10} \mathrm{Pd},{ }^{11} \mathrm{Pt},{ }^{12} \mathrm{Ni},{ }^{13} \mathrm{Ru},{ }^{14} \mathrm{Rh},{ }^{1 \mathrm{lc}, 15,16} \mathrm{Ir}^{16} \mathrm{Cu},{ }^{17} \mathrm{Au},{ }^{18} \mathrm{Co},{ }^{19}$ $\mathrm{In}^{20} \mathrm{Zr}^{21}$ An $(\mathrm{Th}, \mathrm{U})^{22}$, and $\mathrm{Ln}(\mathrm{La}, \mathrm{Sm}, \mathrm{Lu}, \mathrm{Nd}, \mathrm{Y})^{22 \mathrm{~b}}$ are effective for hydrothiolation of unsaturated compounds, but the stereo- and regioselectivity control still remains an important challenge.

In general, regioselectivity in the $\mathrm{X}-\mathrm{H}$ addition across carbon-carbon triple bonds proceeding via $\mathrm{X}-\mathrm{H}$ activation arises from a complex interplay between migratory insertion and reductive elimination steps (Scheme 1). ${ }^{23,24}$ Although electronic and steric properties of the alkyne and the catalyst play an important role, the formation of linear metal-alkenyls via 1,2insertion (a,d) is generally preferred to that of branched isomers via 2,1 insertion $(\mathbf{b}, \mathbf{c}){ }^{25,26}$ Therefore, in a simplified overview, insertion into metal-hydride bond (a) gives rise to linear olefins (anti-Markovnikov or $\beta$-type products) whereas insertion into metal-heteroatom bond (d) generates branched olefins (Markovnikov or $\alpha$-type products). Particularly for hydrothiolation, insertion into metal-hydride bonds is favored with regard to that into metal-thiolate, thus linear vinyl sul- fides are preferably obtained. ${ }^{11 c, 27}$ Preparation of the branched vinyl sulfides, more valuables as synthetic intermediates, ${ }^{3}$ could be accomplished in a controlled manner if a method for directing alkyne insertion into metal-thiolate bonds is developed.

Scheme 1. Pathways for the alkyne migratory insertion into M-H or M-X bonds.

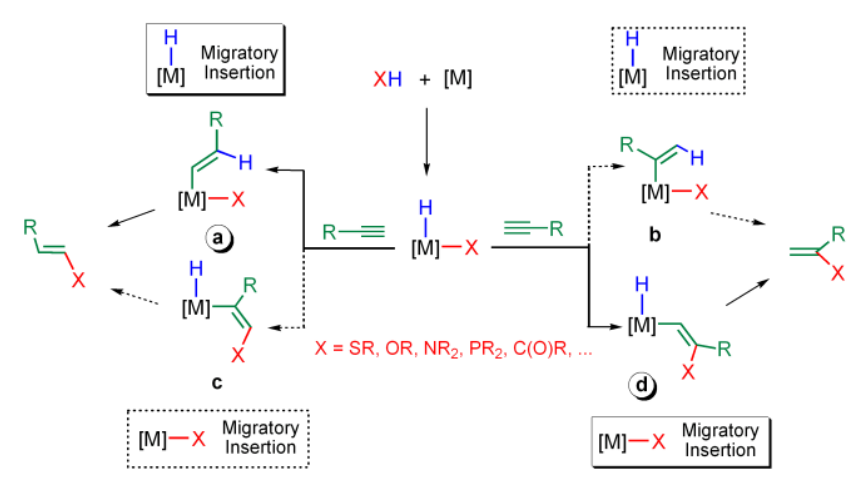

A common strategy for the previously described selective preparation of 1-substituted vinyl sulfides catalyzed by a wide variety of metal complexes is to design active species bearing thiolate ligands and lacking of an hydride moiety (Scheme $2)^{11-13,15 c, 21,22}$ In these catalytic systems the first step is thiolpromoted protonolysis of an anionic ligand present in the precatalyst, or alternatively the formation of a bisthiolate complex accompanied with the release of molecular hydrogen. However, in these cases it is difficult to inhibit the formation 
of byproducts such as disulfide or bis(thio)alkenes. A priori, the formation of these unwanted products should be minimized if a catalytic cycle involving initial S-H oxidative addition to the metal and successive alkyne insertion into metalthiolate bond, and alkenyl-hydride reductive elimination will be operative. Thus, the following question arises: How to favor alkyne M-S insertion in the presence of a hydride ligand? Perhaps the well-established high trans-director capacity of hydrides may be useful. Due to this property, the coordination of the incoming alkyne to the unsaturated hydride-thiolate catalytic intermediate may be channeled at the vacant position trans to the hydride ligand and concomitantly cis to the thiolate, thus favoring the formation of a 2,2-disubstituted alkenyl ligand and subsequently the branched vinyl sulfide. Particularly, $\mathrm{Rh}^{\mathrm{I}}$ complexes are promising precursors to achieve this task as they are efficient catalysts for alkyne hydrothiolation. ${ }^{11 c, 15,16}$ Interestingly, their general tendency to favor linear vinyl sulfides can be reversed by ligand control, as was elegantly shown for $\mathrm{Tp} * \mathrm{Rh}\left(\mathrm{PPh}_{3}\right)_{2}\left(\mathrm{Tp}^{*}=\right.$ hydrotris $(3,5-$ dimethylpyrazolyl)borate) by Love's group. ${ }^{15 \mathrm{~b}, \mathrm{~d}-\mathrm{f}}$

Scheme 2. Strategies directed to the preparation of branched vinyl sulfides.

$$
\mathrm{R}^{1} \mathrm{SH}+[\mathrm{M}]-\mathrm{X} \stackrel{\mathrm{XH}}{\longrightarrow}[\mathrm{M}]-\mathrm{SR}^{1} \stackrel{\equiv \mathrm{R}^{2}}{\longrightarrow}[\mathrm{M}] \underset{\mathrm{SR}^{1}}{-\mathrm{R}^{2}} \stackrel{\mathrm{R}^{1} \mathrm{SH}}{\longrightarrow}=\underset{\mathrm{SR}^{1}}{\mathrm{R}^{2}}+[\mathrm{M}]-\mathrm{SR}^{1}
$$

$[\mathrm{M}]=\mathrm{Pd}, \mathrm{Pt}, \mathrm{Ni}, \mathrm{Th}, \mathrm{Zr}, \mathrm{Rh}$

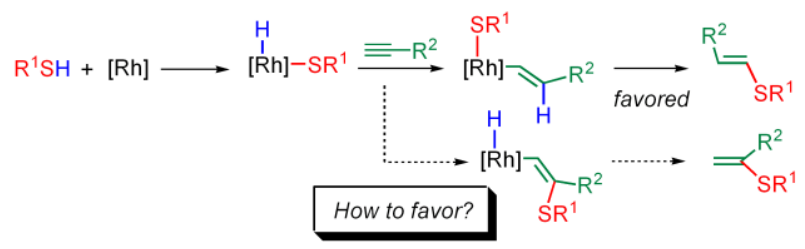

In order to succeed with our proposal, a high control over coordination positions and potential isomerizations within the metal catalytic intermediates is essential. ${ }^{28}$ An $N$-heterocyclic carbene (NHC) ligand may fulfill the aimed requirements due to its special stereoelectronic properties. ${ }^{29}$ The high steric hindrance and powerful electron-donor capacity of bulky NHCs could govern the coordination positions of labile ligands and substrates in the active species, thus determining the selectivity outcome. Indeed, NHC ligands have been revealed as suitable ligands not only for the stabilization of reactive intermediates, but also for the improvement of catalytic activity. In particular, substitution of typical ancillary ligands such as phosphanes by a more electron-donating NHC has extended the scope of many catalytic transformations. ${ }^{30}$ Interestingly, these type of ligands has also been applied to the design of $\mathrm{Ni}^{13 \mathrm{c}} \mathrm{Cu},{ }^{17}$ and $\mathrm{Au}^{18}$ alkyne hydrothiolation catalysts. Herein, we present a catalytic system for the selective hydrothiolation of alkynes based on a rhodium N-heterocyclic carbene framework. A complex interplay between electronic and steric effects exerted by NHC, hydride and pyridine-type ligands accounts for the regioselective formation of branched vinyl sulfides.

\section{RESULTS AND DISCUSSION}

Synthesis of rhodium-NHC catalysts. Dinuclear rhodiumNHC monolefin complexes of type $\left[\mathrm{Rh}(\mu-\mathrm{Cl})(\mathrm{NHC})\left(\eta^{2}-\right.\right.$ olefin) $]_{2}^{31}$ are adequate precursors for a set of catalysts via either a controlled substitution of the $\eta^{2}$-olefin or bridgecleaving reactions by different ligands. Specially, $[\mathrm{Rh}(\mu$ $\mathrm{Cl})(\operatorname{IPr})\left(\eta^{2}\right.$-coe $\left.)\right]_{2}(\mathbf{1})($ coe $=$ cyclooctene; $\mathrm{IPr}=1,3$-bis- $(2,6-$ diisopropylphenyl)imidazol-2-carbene), described by James' group, ${ }^{31 \mathrm{~b}}$ has been successfully applied in our laboratories as starting material for a variety of $\mathrm{Rh}^{\mathrm{I}}$ and $\mathrm{Rh}^{\mathrm{III}}-\mathrm{NHC}$ complexes. ${ }^{32}$ Interestingly, the two coe ligands can be exchanged by bubbling of ethylene through a toluene solution of $\mathbf{1}$ resulting in the formation of the dimer $\left[\mathrm{Rh}(\mu-\mathrm{Cl})(\mathrm{IPr})\left(\eta^{2}-\mathrm{CH}_{2}=\mathrm{CH}_{2}\right)\right]_{2}$ (2) (Scheme 3), which was isolated as a yellow solid in $92 \%$ yield. During the preparation of the manuscript an alternative method for the synthesis of $\mathbf{2}$ has been reported. ${ }^{33}$ The structure of $\mathbf{2}$ has been determined by X-ray analysis on crystals obtained from slow diffusion of $n$-hexane over toluene (see Supporting Information). This structure shows a very different unit cell dimension compared to that reported for $2 \cdot \mathrm{CH}_{2} \mathrm{Cl}_{2}{ }^{33}$

\section{Scheme 3. Synthesis of rhodium-NHC catalysts.}

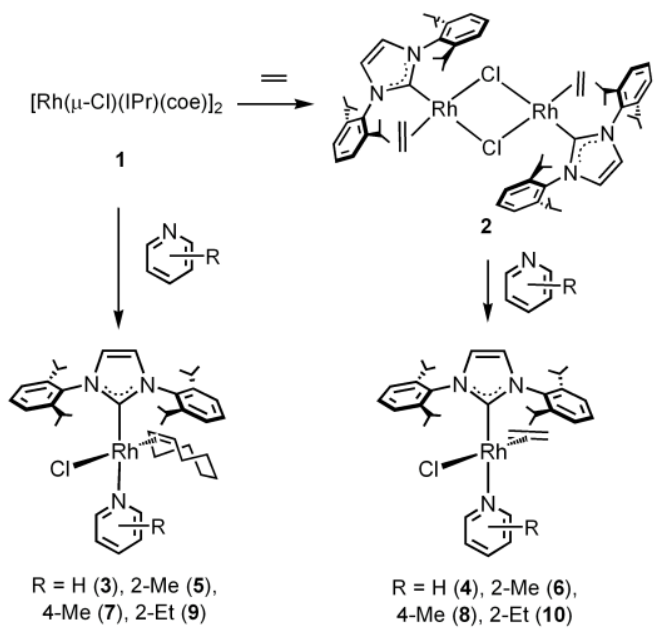

Complex 2 showed a dynamic behavior as it was evidenced in a ${ }^{1} \mathrm{H}$ VT-NMR study. That fact may be ascribed to two rotational processes involving both the $\eta^{2}$-ethylene etb,34 $^{32}$ and the carbene ligands (see Figure 2 for a similar behavior of 4). ${ }^{32 b, 35}$ In the case of IPr, activation parameters were calculated by simulation of the coalescence of the two signals located at $\delta 2.93$ and $2.60 \mathrm{ppm}$ corresponding to the two types of $\mathrm{CH}-$ isopropyl protons $\left(\mathrm{C}_{2}\right.$ symmetry). The values obtained from the corresponding Eyring analysis were $\Delta H^{\neq}=13.9 \pm 0.5 \mathrm{kcal}$ $\mathrm{mol}^{-1}$ and $\Delta S^{\neq}=-1.3 \pm 1.1 \mathrm{cal} \mathrm{K}^{-1} \mathrm{~mol}^{-1}$ for the ethylene rotation and $\Delta H^{\neq}=11.8 \pm 0.4 \mathrm{kcal} \mathrm{mol}^{-1}$ and $\Delta S^{ \pm}=-1.5 \pm 0.9 \mathrm{cal}$ $\mathrm{K}^{-1} \mathrm{~mol}^{-1}$ for the IPr rotation.

The chloro bridges in $\mathbf{1}$ and $\mathbf{2}$ were easily cleaved by nucleophilic pyridine ligands at room temperature, resulting in the formation of the mononuclear complexes $\mathrm{RhCl}(\mathrm{IPr})(\mathrm{L})\left(\eta^{2}-\right.$ coe) $(\mathrm{L}=$ pyridine $(3)$, 2-picoline (5), 4-picoline (7), 2ethylpyridine (9)) and $\mathrm{RhCl}(\mathrm{IPr})(\mathrm{L})\left(\eta^{2}\right.$-ethylene $)(\mathrm{L}=$ pyridine (4), 2-picoline (6), 4-picoline (8), 2-ethylpyridine (10)) which were isolated as yellow solids in $77-86 \%$ yields. ${ }^{36}$ It is noticeable that the alkene ligand was not replaced by pyridine even at $80{ }^{\circ} \mathrm{C}$ in net pyridine overnight. ${ }^{37}$ Monocrystals of $\mathbf{3}$ suitable for X-ray analysis were obtained by slow diffusion of $n$ hexane over a saturated solution of $\mathbf{3}$ in toluene (Figure 1). The complex has distorted square-planar geometry with pyridine and chloro ligands disposed mutually trans to IPr and 
coe, respectively $\left[\mathrm{N}(3)-\mathrm{Rh}-\mathrm{C}(10) \quad 169.36(15)^{\mathrm{o}} ; \quad \mathrm{Cl}-\mathrm{Rh}-\mathrm{Ct}\right.$ $\left.166.02(14)^{\circ}\right]$. The rhodium-carbon separation [Rh-C(10) 1.986(4) A] compares well with previously reported rhodiumNHC single bond distances. ${ }^{29 b}$ The wingtips of IPr, the $\eta^{2}$ olefin and the pyridine adopt an out-of-plane disposition from the square-planar metal environment. ${ }^{38}$

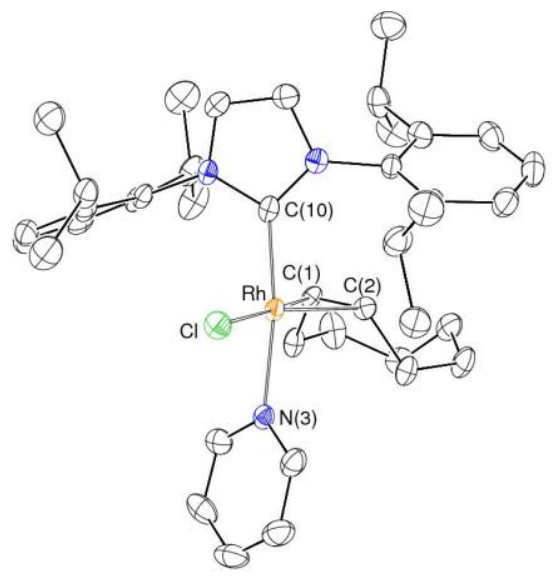

Figure 1. Molecular diagram of 3. Selected bond lengths (A) and angles $\left({ }^{\circ}\right)$ : Rh-Cl(1) 2.3886(13), Rh-N(3) 2.115(4), Rh-C(1) 2.149(4), Rh-C(2) 2.113(4), Rh-C(10) 1.986(4); ClRh-N(3) 84.43(10), Cl-Rh-C(10) 86.21(12), Cl-Rh-Ct 166.02(14), N(3)-Rh-C(10) 169.36(15), N(3)-Rh-Ct 94.42(17), C(10)-Rh-Ct 95.89(18).

The ${ }^{1} \mathrm{H}$ and ${ }^{13} \mathrm{C}\left\{{ }^{1} \mathrm{H}\right\}$ spectra of compounds 3-10 confirm the presence of $\eta^{2}$-olefin, pyridine and IPr ligands. Similarly to $\mathbf{2}$, the IPr and ethylene ligands in $\mathbf{4}$ exhibited restricted rotation (Figure 2). The activation parameters obtained from the rate constants derived from a ${ }^{1} \mathrm{H}$ VT-NMR study and the corresponding Eyring analysis were $\Delta H^{\neq}=13.9 \pm 0.5 \mathrm{kcal} \mathrm{mol}^{-1}$ and $\Delta S^{\neq}=-1.7 \pm 1.2 \mathrm{cal} \mathrm{K}^{-1} \mathrm{~mol}^{-1}$ for the ethylene rotation and $\Delta H^{\neq}=14.1 \pm 0.6 \mathrm{kcal} \mathrm{mol}^{-1}$ and $\Delta S^{ \pm}=-0.7 \pm 1.4 \mathrm{cal} \mathrm{K}^{-1}$ $\mathrm{mol}^{-1}$ for the IPr rotation. The values obtained for the rotation of ethylene in $\mathbf{4}$ are almost identical to that calculated for the dimer 2. In contrast, the barrier for the rotation of IPr around the $\mathrm{Rh}-\mathrm{C}$ axis in $\mathbf{4}$ is $2.3 \mathrm{kcal} \mathrm{mol}^{-1}$ higher than in $\mathbf{2}$.
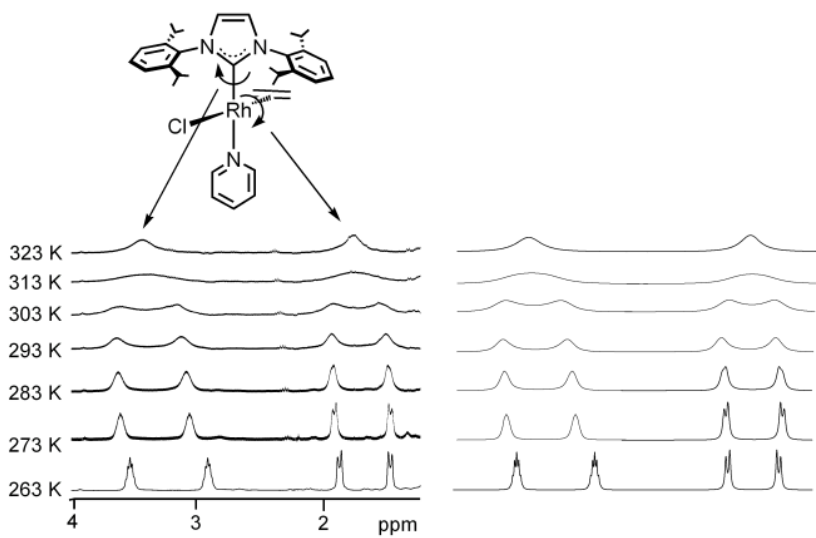

Figure 2. Variable-temperature ${ }^{1} \mathrm{H}-\mathrm{NMR}$ spectra of $\mathrm{RhCl}(\mathrm{IPr})($ pyridine $)\left(\eta^{2}\right.$-ethylene) (4) in $\mathrm{CD}_{2} \mathrm{Cl}_{2}$ showing the coalescence of the $\mathrm{CH}$-isopropyl and ethylene resonances: experimental (left) and calculated (right).

The rotation barrier for the IPr ligand is also affected by the nature of the $\eta^{2}$-olefin. Thus, substitution of ethylene by coe slightly hinders the rotational process as it is observed from the parameters calculated for $3\left(\Delta H^{\neq}=15.1 \pm 0.7 \mathrm{kcal} \mathrm{mol}^{-1}\right.$ and $\left.\Delta S^{ \pm}=-0.4 \pm 1.9 \mathrm{cal} \mathrm{K}^{-1} \mathrm{~mol}^{-1}\right)$. Similar values for $\mathrm{IPr}$ rotation were calculated for complex $\mathbf{6}$ bearing a 2-picoline ligand $\left(\Delta H^{\neq}=15.0 \pm 0.7 \mathrm{kcal} \mathrm{mol}^{-1}\right.$ and $\Delta S^{ \pm}={ }^{-} 1.6 \pm 1.6 \mathrm{cal}$ $\left.\mathrm{K}^{-1} \mathrm{~mol}^{-1}\right)$. However, in this case, four $\mathrm{CH}$-isopropyl signals were observed at low temperature $(\delta 4.37,4.09,3.09$, and 2.62 ppm) which coalesced into two at 4.17 and $2.91 \mathrm{ppm}$. This fact can be explained by hindered rotation of 2-picoline, that breaks the plane of symmetry.

The presence of a substituent in the 2-position of pyridine not only affects the rotation of the ligand but also the coordination to the metallic center. Thus, a temperature-dependent dynamic equilibrium between $\mathbf{6}$ and 2 , as a result of the decoordination of 2-picoline, was observed between 293 and $353 \mathrm{~K}$ (Figure 3). Thermodynamic parameters calculated from the Van't Hoff representations ( $\mathrm{Ln} \mathrm{K}_{\mathrm{eq}}$ vs $1 / \mathrm{T}$ ) were $\Delta H^{\circ}=$ $14.4 \pm 0.5 \mathrm{kcal} \mathrm{mol}^{-1}$ and $\Delta S^{\mathrm{O}}=32.5 \pm 1.3 \mathrm{cal} \mathrm{K}^{-1} \mathrm{~mol}^{-1}$. The process is endothermic whereas the slightly positive $\Delta S^{0}$ agrees well with an increase of internal disorder in the products due to decoordination of 2-picoline. It seems clear that an ortho-substituent on pyridine hinders the coordination of the ligand to the metallic center. In accordance to this, the disubstituted 2,6-dimethylpyridine was found unable to cleave the chloro bridges in 1-2.

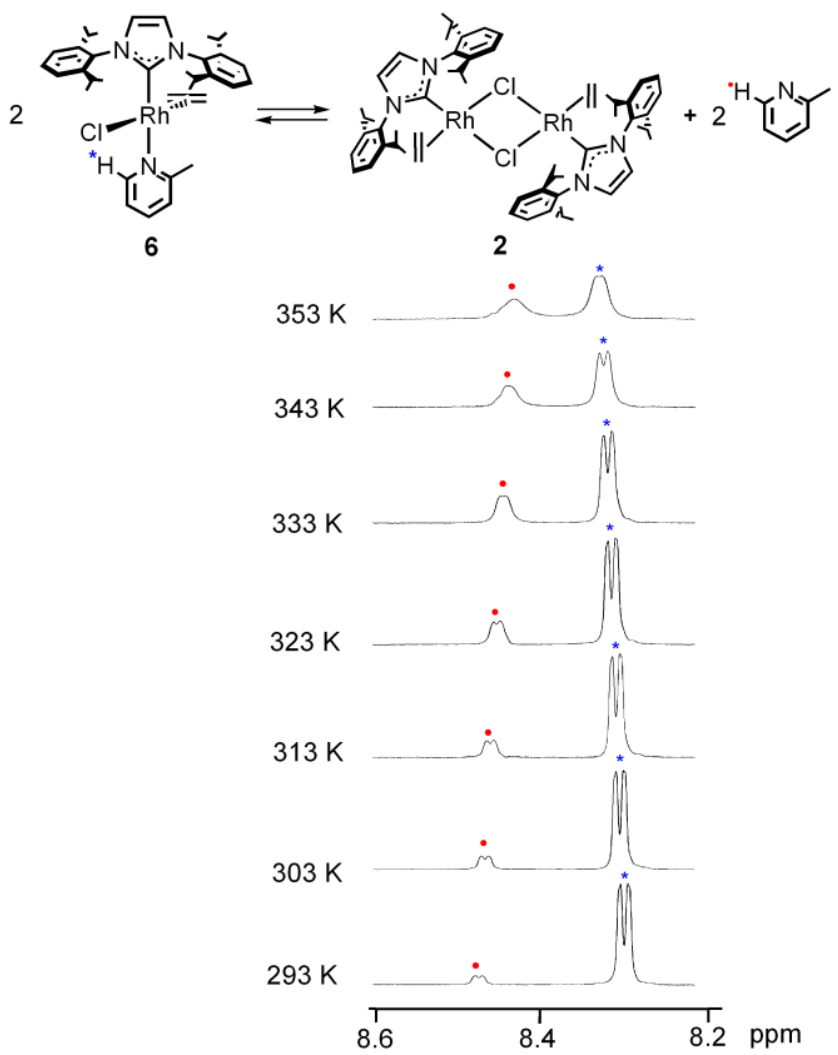

Figure 3. Variable-temperature ${ }^{1} \mathrm{H}-\mathrm{NMR}$ spectra in the ortho-piridine proton region for the dynamic equilibrium between $\mathbf{6}$ and $\mathbf{2}$. 
Alkyne hydrothiolation catalytic studies. Wilkinson's catalyst $\mathrm{RhCl}\left(\mathrm{PPh}_{3}\right)_{3}$ has been previously revealed as an active catalyst for alkyne hydrothiolation. ${ }^{11,15 e}$ In view that the substitution of phosphanes by a more electron-donating NHC has extended the scope of many catalytic transformations, ${ }^{30}$ we have studied that effect in the present transformation (eq. 1). Addition of thiophenol to phenylacetylene was chosen as benchmark reaction (Table 1). Catalytic reactions using a 1:1 thiol:alkyne ratio were monitored in an NMR tube in $\mathrm{C}_{6} \mathrm{D}_{6}$ at $25^{\circ} \mathrm{C}$ with 2 mol \% catalyst loading. A catalytic test with $\mathrm{RhCl}\left(\mathrm{PPh}_{3}\right)_{3}$ under our mild standard conditions showed high initial catalytic activity but also catalyst deactivation at about $80 \%$ conversion, displaying a high preference for the $\beta-E$ isomer (entry 1). In contrast, $\mathrm{RhCl}(\mathrm{IPr})\left(\mathrm{PPh}_{3}\right)_{2}{ }^{31 \mathrm{~b}}$ showed full conversion to clean addition products after $3 \mathrm{~h}$ at room temperature with a selectivity switch to $53 / 47 \beta$-E/ $\alpha$ (entry 2). Although Wilkinson's catalyst is initially more active than $\mathrm{RhCl}(\mathrm{IPr})\left(\mathrm{PPh}_{3}\right)_{2}$, the catalyst stability gained by the introduction of a IPr ligand compensates the loss of activity. Then, other phosphane-free Rh-NHC derivatives were tested as catalysts precursors. RhClIPr $(\operatorname{cod})^{39} \quad(\operatorname{cod}=1,5-$ cyclooctadiene) reacts very slowly (18\% after $24 \mathrm{~h}$, entry 3 ) but the dinuclear $\eta^{2}$-coe compound $\mathbf{1}$ surpassed the activity observed for $\mathrm{RhCl}(\mathrm{IPr})\left(\mathrm{PPh}_{3}\right)_{2}$ while maintaining clean full conversion and the preference for the anti-Markovnikov products (entry 4). The strong coordination of cod ligand in the former compared to the labile coe ligands in $\mathbf{1}$ may be determinant for the very different catalytic activity.

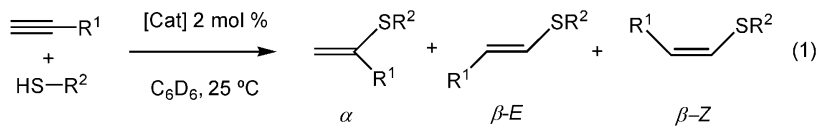

Table 1. Phenylacetylene Hydrothiolation with thiophenol at $25^{\circ} \mathrm{C} .^{a}$

\begin{tabular}{|c|c|c|c|c|c|}
\hline Entry & Catalyst & $t(h)$ & conv. & $\beta-E / \alpha$ & $\operatorname{TOF}_{1 / 2}\left(h^{-1}\right)^{b}$ \\
\hline 1 & $\mathrm{RhCl}\left(\mathrm{PPh}_{3}\right)_{3}$ & 0.5 & 80 & $92 / 8$ & 300 \\
\hline 2 & $\mathrm{RhCl}(\mathrm{IPr})\left(\mathrm{PPh}_{3}\right)_{2}$ & 3 & 99 & $53 / 47$ & 55 \\
\hline 3 & $\mathrm{RhCl}(\mathrm{IPr})(\mathrm{cod})$ & 24 & 18 & $68 / 32$ & - \\
\hline 4 & 1 & 1 & 99 & $73 / 27$ & 280 \\
\hline 5 & 2 & 0.4 & 99 & $67 / 33$ & 482 \\
\hline 6 & 3 & 4 & 99 & $9 / 91$ & 38 \\
\hline 7 & 4 & 3 & 99 & $11 / 89$ & 59 \\
\hline 8 & 6 & 2.2 & 99 & $58 / 42$ & 105 \\
\hline 9 & 8 & 4 & 99 & $13 / 87$ & 41 \\
\hline 10 & 10 & 1.6 & 99 & $62 / 38$ & 125 \\
\hline 11 & $\mathbf{1}+1$ equiv py & 4 & 99 & $10 / 90$ & 38 \\
\hline 12 & $2+1$ equiv py & 3 & 99 & $12 / 88$ & 59 \\
\hline 13 & $2+10$ equiv py & 7 & 99 & $6 / 94$ & 22 \\
\hline 14 & $2+10$ equiv & 6 & 99 & $37 / 63$ & 30 \\
\hline 15 & none & 24 & 37 & $8 / 92^{c} / 0$ & -- \\
\hline 16 & pyridine $^{d}$ & 24 & 13 & $9 / 91^{c} / 0$ & -- \\
\hline
\end{tabular}

$\begin{array}{llllll}17 & 1+10 \text { equiv } \mathrm{NEt}_{3} & 7 & 99 & 59 / 41 & 28\end{array}$

$\begin{array}{llllll}18 & 1+\mathrm{BHT} & 1 & 99 & 72 / 28 & 300\end{array}$

${ }^{a} 0.5 \mathrm{~mL}$ of $\mathrm{C}_{6} \mathrm{D}_{6}$ with $2 \mathrm{~mol} \%$ of catalyst. [subs] $=1 \mathrm{M} .{ }^{b}$ Determined at $50 \%$ conversion. ${ }^{c}$ Yield of $\beta$-Z. ${ }^{d} 20 \mathrm{~mol} \%$ of pyridine.

The exchange of coe ligands by ethylene in dimer 2 enhanced catalytic rate with similar preference to the linear isomer (entry 5). Surprisingly, catalysts 3 and 4, bearing a pyridine moiety, showed reverse regioselectivity although also a moderate decrease of catalytic activity (entries 6-7). The insitu addition of 1 equiv of pyridine to $\mathbf{1}$ and $\mathbf{2}$ gave similar results to 3 and $\mathbf{4}$, respectively (entries 11-12). It was observed that an increase of the amount of pyridine in the reaction media switches the equilibrium to the Markovnikov isomer up to $94 \%$ with the catalytic system $\mathbf{2}+10$ equiv of pyridine (entry 13) (Figure 4). Only traces of disulfide were detected by GCMS analysis whereas $\beta$-Z product was not observed in any of the catalytic runs carried out with 1-4. A blank test without metal catalysts showed after $24 \mathrm{~h}$ the formation of $37 \%$ of linear vinyl sulfides of mainly $Z$ configuration probably via radical process (entry 15). ${ }^{40}$ Addition of 2,6-di-tert-butyl-4methylphenol (BHT) to a sample catalyzed by $\mathbf{1}$ did not affect either the activity or the selectivity, thus excluding a mechanism via radical species operating with our catalysts (entry 18). Addition of pyridine to the blank test did not increase activity but rather slightly reduced it (entry 16). In order to discard that pyridine acts as a base, $\mathrm{NEt}_{3}$ was added to a sample catalyzed by $\mathbf{1}$. The ratio of the products was only slightly switched to the branched isomers (compare entries 4 vs 17). To further assess that the positive role of pyridine is played on coordination to active species, the catalytic activity of complexes 6, 8, and $\mathbf{1 0}$ having 2-picoline, 4-picoline or 2ethylpyridine ligands, respectively, was studied (entries 8-10). Complex 8 gave similar results than 4 but catalysts 6 and 10, bearing 2-substituted pyridines, showed a behavior between 2 and 4 both in terms of activity and selectivity. The hindered coordination of 2-picoline and 2-ethylpyridine, as showed in figure 3 , can be the reason for this result. Indeed, displacement of the equilibrium to the coordinated species by addition of 10 equiv of 2-picoline to $\mathbf{2}$ resulted in an increase of the regioselectivity to the $\alpha$-isomer (compare entries 8 vs 14).

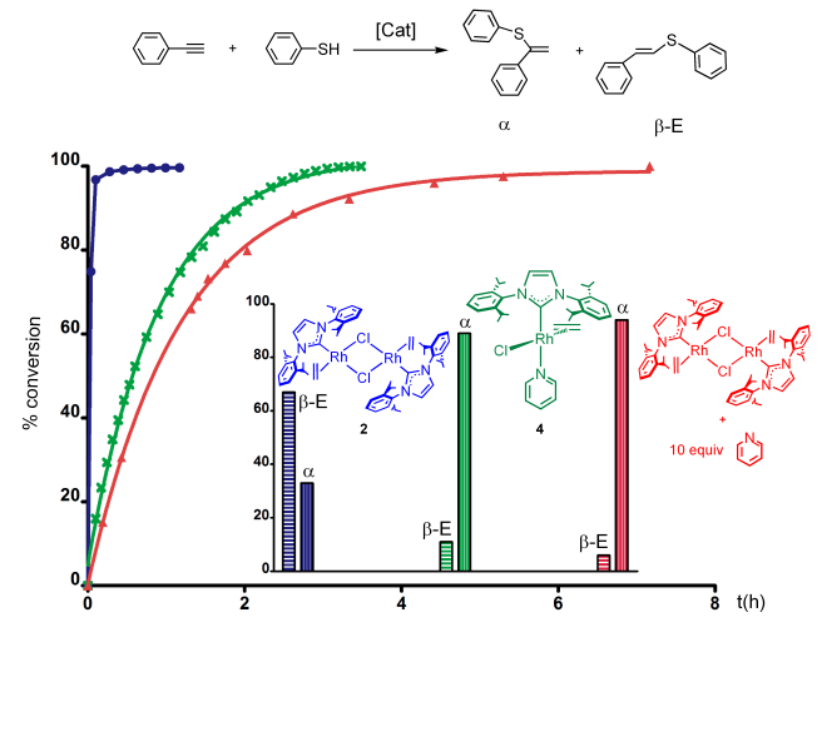


Figure 4. Catalytic activity and regioselectivity outcome in hydrothiolation of phenylacetylene with thiophenol for catalysts $\mathbf{2}(\bullet), \mathbf{4}(\times), \mathbf{2}+10$ equiv pyridine $(\Delta)$.

Compounds 1-4 are versatile catalyst precursors. They promote the addition of thiophenol to different alkylic and aromatic alkynes (Table 2). The reaction rates for the alkylic ones were lower than those observed for phenylacetylene and thus the reactions were performed at $50{ }^{\circ} \mathrm{C}$. Strikingly, the "pyridine effect" on the regioselectivity was maintained. The amount of the Markovnikov thioether product in the hydrothiolation of 1-hexyne was increased from 39/61 (2) to $22 / 78$ by using the pyridine complex 4 as catalyst (entries 1-2). Moreover, up to $96 \%$ of branched isomer was obtained using $\mathbf{2}+10$ equiv py as catalytic system with no significant isomerization to internal vinyl thioether. In the case of the enyne 1ethynyl-1-cyclohexene a similar behavior was observed but it is noteworthy the complete chemoselectivity with the exclusive addition of $\mathrm{PhSH}$ to the triple bond. More interestingly, the internal alkyne 3-hexyne gave exclusively the $E$-isomer (entry 7, eq 2) resulting from a syn addition of the thiol which, in addition to the absence of the $\beta-Z$ isomer thorough the different catalytic tests, point to a migratory insertion mechanism for the alkyne hydrothiolation with these systems. The effect of modifying the electron density on the aromatic ring of phenylacetylene has been also studied. The introduction of an electron-donating group at the para position decreased both activity and selectivity (compare entry 8, table 2 vs entry 11 , table 1) whereas the presence of an electron-withdrawing substituent resulted in higher TOF and regioselectivity (entry 9). A propargyl ether was also effective with similar isomeric distribution (entry 10).

Table 2. Alkyne Hydrothiolation with thiophenol. ${ }^{a}$

\begin{tabular}{|c|c|c|c|c|c|c|c|}
\hline Entry & Alkyne & Cat & $\mathrm{T}\left({ }^{\circ} \mathrm{C}\right)$ & $\mathrm{t}(\mathrm{h})$ & conv. & \multicolumn{2}{|c|}{$\beta-E / \alpha \mathrm{TOF}_{1 / 2}\left(\mathrm{~h}^{-1}\right)$} \\
\hline 1 & & 2 & 50 & 7 & 99 & $39 / 61$ & 25 \\
\hline 2 & & 4 & 50 & 9.4 & 99 & $22 / 78$ & 19 \\
\hline \multirow[t]{2}{*}{3} & & $2+$ & 50 & 24 & 95 & $4 / 96$ & 1 \\
\hline & & \multicolumn{2}{|c|}{10 equiv py } & & & & \\
\hline 4 & & 2 & 50 & 3.5 & 99 & $62 / 38$ & 47 \\
\hline 5 & & 4 & 50 & 5.5 & 99 & $49 / 51$ & 30 \\
\hline \multirow[t]{2}{*}{6} & & $2+$ & 50 & 13 & 92 & $34 / 66$ & 16 \\
\hline & & \multicolumn{2}{|c|}{10 equiv py } & & & & \\
\hline \multirow[t]{3}{*}{7} & & 2 & 50 & 20 & 95 & $--^{b}$ & 1 \\
\hline & & $2+$ & 25 & 18 & 99 & $10 / 90$ & 7 \\
\hline & & \multicolumn{2}{|c|}{10 equiv py } & & & & \\
\hline \multirow{2}{*}{\multicolumn{2}{|c|}{$9 \mathrm{~F}_{3} \mathrm{C}-$}} & $2+$ & 25 & 4 & 99 & $3 / 97$ & 45 \\
\hline & & \multicolumn{2}{|c|}{10 equiv py } & & & & \\
\hline \multirow[t]{2}{*}{10} & & $2+$ & 50 & 18 & 99 & $10 / 90$ & 7 \\
\hline & & \multicolumn{2}{|c|}{10 equiv py } & & & & \\
\hline
\end{tabular}

${ }^{a} 0.5 \mathrm{~mL}$ of $\mathrm{C}_{6} \mathrm{D}_{6}$ with $2 \mathrm{~mol} \%$ of catalyst. [subs] $=1 \mathrm{M} .^{b}$ exclusive formation of (E)-3-phenylsulfanyl-3-hexene.

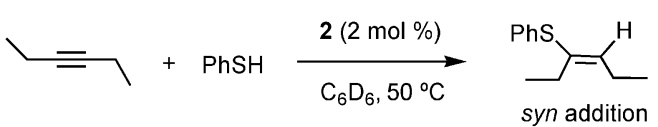

The scope of the catalysts was investigated by using different thiols (Table 3). Again, the regioselectivity can be tuned by pyridine addition. Benzyl hydrosulfide, $\mathrm{PhCH}_{2} \mathrm{SH}$, reacted much faster than $\mathrm{PhSH}$ (entries 1-4). In fact, full conversion was attained with 2 after the first recorded ${ }^{1} \mathrm{H}$ NMR spectrum $(\approx 3$ min) with our standard conditions. A reduction of the amount of catalyst 2 to $0.5 \mathrm{~mol} \%$ gave the same result, with a calculated TOF of $4000 \mathrm{~h}^{-1}$. As it was previously shown for $\mathrm{PhSH}$, catalyst 4 and the catalytic system $2+10$ equiv py were less active but much more selective to the $\alpha$-isomer. A doubly protected N-tert-butoxycarbonyl (Boc) and methylester cysteine was also transformed into the vinyl thioether with high activity under mild conditions $\left(\right.$ TOF $_{1 / 2}$ of $250-580 \mathrm{~h}^{-1}$ ) (entries 5-7). Thus, our catalysts are compatible with other functional groups giving good selectivities to the $\alpha$ vinyl sulfide isomer. Indeed, functionalization of cysteine is an important goal for the synthesis of biologically active derivatives. Interestingly, 1,6-hexanedithiol undergoes a double addition process with good selectivity to the $\alpha, \alpha$ product ( $88 \%$, entry 8 , eq 3 ).

Table 3. Hydrothiolation of phenylacetylene with different thiols at $25^{\circ} \mathrm{C} .{ }^{a}$

\begin{tabular}{|c|c|c|c|c|c|c|}
\hline Entry & Thiol & Catalyst & $\mathrm{t}(\mathrm{h})$ & conv. & $\beta-E / \alpha$ & $\operatorname{TOF}_{1 / 2}\left(\mathrm{~h}^{-1}\right)$ \\
\hline 1 & & 2 & 0.05 & 99 & $33 / 67$ & -- \\
\hline 2 & & $2^{c}$ & 0.05 & 99 & $31 / 69$ & $4000^{b}$ \\
\hline 3 & & 4 & 0.08 & 99 & $26 / 74$ & $625^{b}$ \\
\hline 4 & & $2+$ & 0.4 & 99 & $7 / 93$ & 510 \\
\hline & & 0 equiv $p$ & & & & \\
\hline 5 & & 2 & 0.25 & 99 & $37 / 63$ & 580 \\
\hline 6 & & 4 & 0.5 & 99 & $23 / 77$ & 420 \\
\hline 7 & & $2+$ & 1.2 & 99 & $10 / 90$ & 250 \\
\hline & & 0 equiv $p$ & & & & \\
\hline 8 & & $2+$ & 0.7 & 99 & $11 / 88^{d}$ & .390 \\
\hline & & 0 equiv $p$ & & & & \\
\hline
\end{tabular}

${ }^{a} 0.5 \mathrm{~mL}$ of $\mathrm{C}_{6} \mathrm{D}_{6}$ with $2 \mathrm{~mol} \%$ of catalyst. [subs] $=1 \mathrm{M} .{ }^{b}$ Measured at full conversion. ${ }^{c} 0.5 \mathrm{~mol} \%$ of $2{ }^{d}$ ratio between $\beta$-E, $\alpha$ and $\alpha, \alpha$.

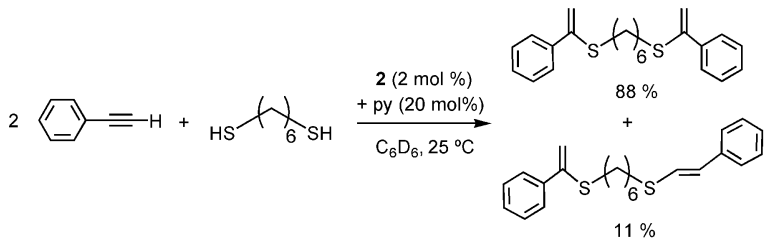

Mechanistic proposal. A number of possible mechanisms for alkyne hydrothiolation have been postulated. The transaddition product, $\beta-Z$ vinyl sulfides, are mainly formed in the 
absence of catalyst via a radical pathway. ${ }^{40}$ In our catalytic system the inversion of regioselectivity promoted by pyridine addition do not proceed by radical intermediates as the addition of a radical trap (BHT) did not influence either the activity or the selectivity. On the other hand, the external attack of the thiol on a coordinated alkyne is unlikely as the exclusive formation of the $s y n$-addition $\beta$ - $E$ vinyl sulfide product was observed in the hydrothiolation of internal alkynes. In fact, we fail to detect any well-defined compound from the addition of a stoichimetric amount of phenylacetylene to $\mathbf{1}$ or $\mathbf{3}$. Thus, the above results suggest a classical $\mathrm{S}-\mathrm{H}$ oxidative addition and successive alkyne insertion and reductive elimination processes as the plausible mechanism operating with our catalysts (Scheme 1).

In order to shed light on the effect of pyridine coordination on the regioselectivity outcome, several stoichiometric NMR experiments were carried out. Treatment of $\mathbf{1}$ with thiophenol gave rise to an unidentified mixture of rhodium-hydrides, probably originated from oxidative addition of $\mathrm{PhSH}^{41}$ In fact, the formation of several mononuclear or dinuclear thiolate- or chloro-bridged complexes can be envisaged. ${ }^{42}$ However, when the pyridine complex 3 was treated with $\mathrm{PhSH}$, a doublet at $26.55 \mathrm{ppm}$ with a $J_{\mathrm{Rh}-\mathrm{H}}=48.5 \mathrm{~Hz}$ appeared as the main hydride species, along with the presence of free coe. The upfield shift and the high coupling constant of this resonance suggest a square-pyramidal structure with the hydride occupying the apical position. ${ }^{32 \mathrm{a}, 43}$ Unfortunately, complex $\mathrm{RhClH}(\mathrm{SPh})(\mathrm{IPr})(\mathrm{py})$ (11) could not be isolated. Addition of 1 equiv of phenylacetylene at $-20{ }^{\circ} \mathrm{C}$ to an NMR sample of $\mathbf{1 1}$ generated in-situ led to smoothly formation of the organic product phenyl(1-phenylvinyl)sulfane, resulting from the Markovnikov addition of $\mathrm{PhSH}$ to the alkyne, and a mixture of unidentified rhodium species with concomitant disappearance of the hydride signal. The fact that alkenyl intermediates could not be detected points to the migratory insertion as the ratedetermining step. In accordance to this, alkyl thiols react faster than thiophenol. Although the more acidic thiophenol facilitates the oxidative addition step, the more basic sulfur atom of alkyl thiolate ligands should favor the migratory insertion. Indeed, the observation that an electron-withdrawing group at para position of the aromatic ring of phenylacetylene increases the activity is in accordance with this proposal. The insertion of alkyne into the Rh-S bond should be facilitated by a decrease in the electronic density on the $\mathrm{C}-\mathrm{C}$ triple bond.

It seems likely that the oxidative addition of the thiophenol to $\mathbf{3}$ generates an unsaturated pentacoordinated complex $\mathbf{1 1}$, via decoordination of the olefin on the electron-poor $\mathrm{Rh}^{\text {III }}$ intermediate, with the pyridine occupying the less congested trans position regarding to the high sterically demanding IPr. Indeed, DFT calculations on the stability of different unsaturated square-pyramidal isomers with pyridine (11a), chloride (11b), and thiolate (11c) located trans to IPr, showed that 11a is 13.5 and $14.3 \mathrm{kcal} \mathrm{mol}^{-1}$ more stable than $\mathbf{1 1 b}$ and 11c, respectively (Figure 5). The trigonal bypiramidal structure for these species was not found as minima in any case. In addition, the bulky IPr ligand makes difficult the coordination of the amine ligands in the equatorial position. In fact, several studies on saturated complexes having two pyridine ligands have shown that the pyridine ligand cis to IPr is more labile or even decoordinates on increasing the steric demand on the NHC ligand. ${ }^{44}$

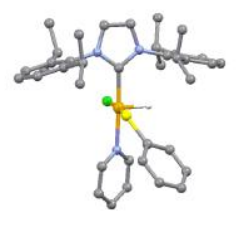

$11 \mathrm{a}$

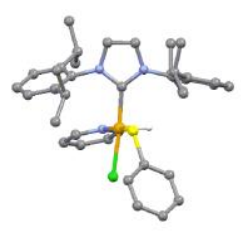

$11 \mathrm{~b}$

$13.5 \mathrm{kcal} \mathrm{mol}^{-1}$

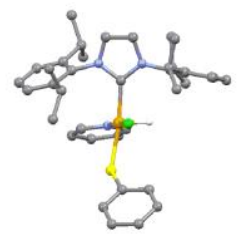

$11 \mathrm{c}$

$14.3 \mathrm{kcal} \mathrm{mol}^{-1}$
Figure 5. DFT computed energies for the pentacoordinated square-pyramidal structures of $\mathbf{1 1}$.

In contrast to the behavior observed for $\mathbf{3}$, the treatment of $\mathbf{1}$ with 1 equiv of $\mathrm{PhSH}$ and 3 equiv of pyridine per metal atom in tol- $d_{8}$ gave rise to a mixture of two hydride species in dynamic equilibrium: the unsaturated complex 11 and the saturated $\mathrm{RhClH}(\mathrm{SPh})(\mathrm{IPr})(\mathrm{py})_{2}$ (11-py), which exhibited a doublet at $\delta-16.95 \mathrm{ppm}$ with $J_{\mathrm{Rh}-\mathrm{H}}=15.6 \mathrm{~Hz}$, in $1: 2.5$ ratio at 20 ${ }^{\circ} \mathrm{C}$. The new saturated octahedral 11-py results from the coordination of pyridine ligand in 11. Similar downfield shift and reduction of the $J_{\mathrm{Rh}-\mathrm{H}}$ coupling constant has been previously observed in related rhodium complexes by coordination of pyridine to the vacant site of the square-pyramidal hydride precursors. $^{45}$

A ${ }^{1} \mathrm{H}$ VT-NMR study confirmed the dynamic equilibrium between 11 and 11-py (Figure 6). As can be seen in the right part of the figure, that shows the hydride region of the spectra, on lowering the temperature from 303 to $243 \mathrm{~K}$ the intensity of the hydride signal corresponding to $\mathbf{1 1}$ diminishes and shifts to lower field approaching to that of 11-py which slightly broadens. More informative is the left part of the figure. The ortho-protons of the pyridine ligand of $\mathbf{1 1}(\bullet)$ integrates by 2 related to the hydride located at upfield shift, which suggests the free rotation of the pyridine ligand that makes both ortho-protons equivalents. This resonance does not change much with temperature. In contrast, the ${ }^{1} \mathrm{H}$ NMR spectrum at $243 \mathrm{~K}$ of 11-py displays three signals for the four orthopyridine protons. The resonance at $9.06 \mathrm{ppm}$ integrates $2: 1$ with respect to the hydride signal at $-16.27 \mathrm{ppm}$ and it is assigned to the both ortho-pyridine protons of the ligand trans to $\operatorname{IPr}(\ddagger)$. In contrast, the signals corresponding to the pyridine ligand cis to IPr in 11-py ( $\square$ ) split into two resonances at 9.58 and $9.31 \mathrm{ppm}$, probably by hindered rotation of the pyridine due the proximity of bulky IPr. At higher temperature these resonances coalesce to a single resonance over $263 \mathrm{~K}$ and exchange with that corresponding to free pyridine (\#). Interestingly, the hydride signal for $\mathbf{1 1}$ shifts to lowfield at low temperature but remains unchanged over $303 \mathrm{~K}$. This observation suggests that $\mathbf{1 1}$ is likely involved in another equilibrium, probably a dimerization process, resulting in the saturation of the vacant site. ${ }^{42}$

Coordination of pyridine cis to IPr is not exclusively determined by the sterical pressure of the carbene ligand. Treatment of 1 with 1 equiv of benzylthiol and 3 equiv of pyridine per metal atom resulted in the exclusive formation of a pyridinesaturated hydride complex $\mathrm{RhClH}\left(\mathrm{SCH}_{2} \mathrm{Ph}\right)(\mathrm{IPr})(\mathrm{py})_{2}$ (12-py) (Figure 7). The ${ }^{1} \mathrm{H}$ VT-NMR spectra of 12-py are very similar to that of 11-py. In particular, the hydride ligand was observed as a doublet at $\delta-17.31 \mathrm{ppm}$ with $J_{\mathrm{Rh}-\mathrm{H}}=15.0 \mathrm{~Hz}$ at $25^{\circ} \mathrm{C}$. In 
the ortho-pyridine region a doublet at $9.28 \mathrm{ppm}\left(J_{\mathrm{H}-\mathrm{H}}=5.2\right.$ $\mathrm{Hz}$ ) corresponds to the pyridine ligand trans to IPr whereas the cis pyridine ligand splits into two signals at 9.45 and $9.19 \mathrm{ppm}$ at $243 \mathrm{~K}$. However, there is no equilibrium between 12-py and the potential unsaturated compound 12. Benzylthiolate is more flexible than phenylthiolate and thus complex 12-py can accommodate a second pyridine ligand more easily than 11-py. The steric influence of the ancillary ligands also affects the potential coordination of a $\mathrm{N}$-donor ligand trans to the hydride ligand, as observed in the in-situ formation of the 2ethylpyridine complex $\mathrm{RhClH}\left(\mathrm{SCH}_{2} \mathrm{Ph}\right)(\mathrm{IPr})(\mathrm{Et}-\mathrm{py})(\mathbf{1 3})$. The increase of the steric bulk exerted by the 2-ethylpyridine prevents the formation of the saturated complex 13-py and thus, the clean formation of square-pyramidal 13 was observed $(\delta-$ $26.93 \mathrm{ppm}, J_{\mathrm{Rh}-\mathrm{H}}=47.0 \mathrm{~Hz}$ ).
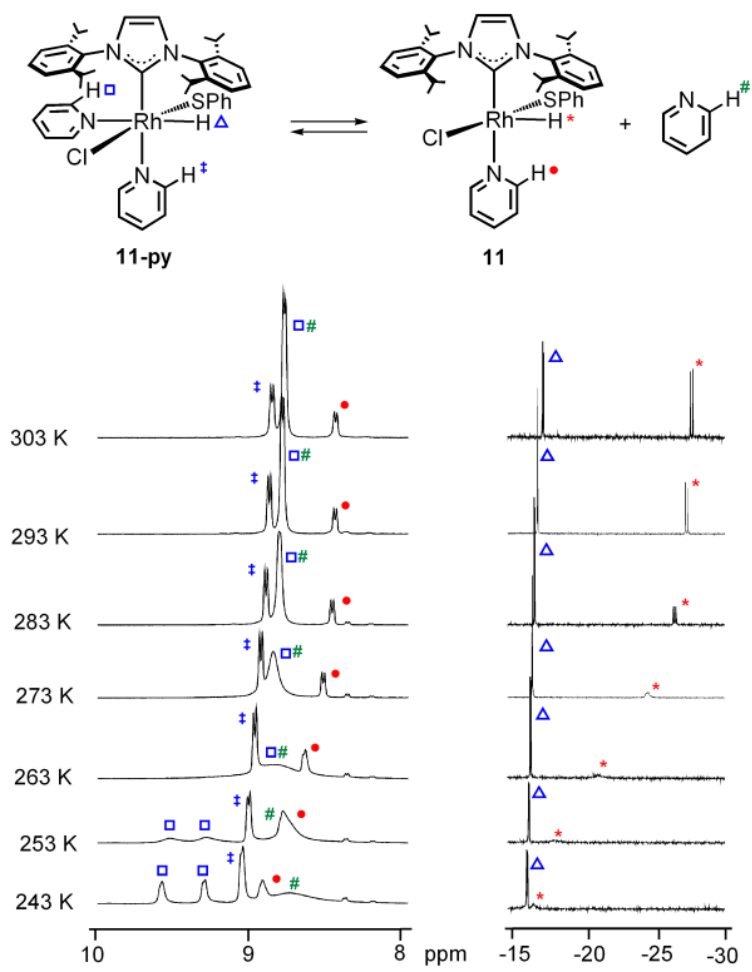

Figure 6. Stacked plot of variable-temperature ${ }^{1} \mathrm{H}$ NMR spectra in tol- $d_{8}$ in the ortho-pyridine (left) and hydride (right) regions of the equilibrium between 11 and 11-Py

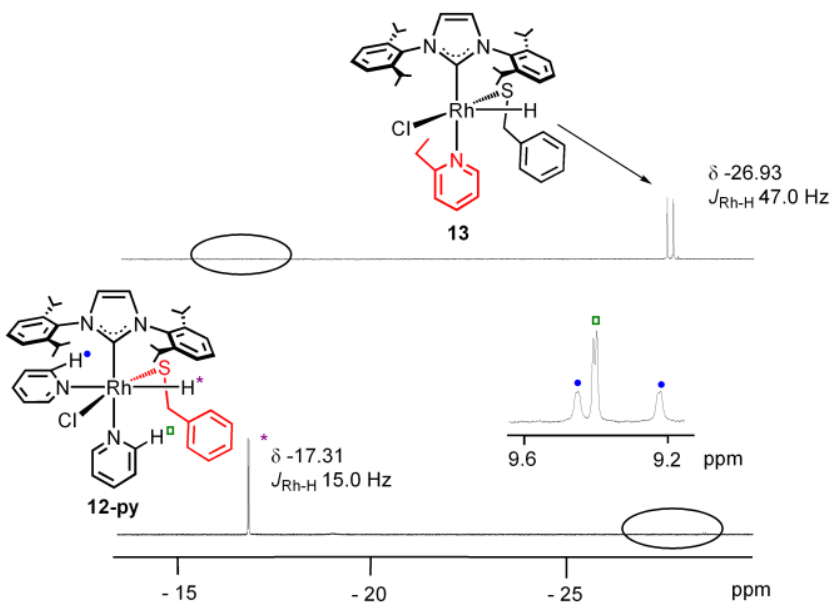

Figure 7. ${ }^{1} \mathrm{H}$ NMR spectra in tol- $d_{8}$ at $223 \mathrm{~K}$ for 12-py (octahedral) and 13 (square-pyramidal).

The unsaturated square-pyramidal species a similar to 11, is the key for the explanation of the observed regioselectivity outcome (Scheme 4). The high trans influence of the hydride ligand determines the stereochemistry of the complex and directs the coordination of the incoming ligand (alkyne or pyridine) trans to it (b). Therefore the alkyne is now located in cis disposition regarding to the thiolate ligand thus favorig migratory insertion between both groups to generate a 2,2disubstituted alkenyl ligand (c). ${ }^{46}$ Reductive elimination within c generates a branched vinyl sulfide. The influence of the pyridine excess on the activity and regioselectivity should be related with an increase of the concentration of $\mathbf{a}$ in the reaction media. Although the formation of the species such as 11-py may retard the alkyne coordination, resulting in an inferior catalytic activity as it was observed for the catalytic system $2+10$ equiv pyridine, it could also help to prevent both the decoordination of pyridine and the isomerization of a thus increasing the selectivity. In fact, decoordination of pyridine give rise to an hypothetical square-pyramidal pentacoordinated species $\mathbf{d}$ with the alkyne trans to IPr and cis to both hydride and thiolate ligands where insertion into $\mathrm{Rh}-\mathrm{H}$ or $\mathrm{Rh}-\mathrm{S}$ bonds is now possible therefore accounting for an unselective catalytic outcome. Catalytic pathway via $\mathbf{d}$ is probably operating with the dinuclear catalyst precursors $\mathbf{1}$ and 2, or the phosphane catalyst $\mathrm{RhCl}(\mathrm{IPr})\left(\mathrm{PPh}_{3}\right)_{2}$, which exhibit good activity but moderate regioselectivity. In the case of 2 subtituted pyridine complexes 5, 6, 9, and $\mathbf{1 0}$ the steric repulsion between the substituent and the incoming alkyne reduces the ability for these catalyst to generate b-type intermediates and also favors pyridine decoordination, as shown in figure 3 , driven the catalytic reaction through type $\mathbf{d}$ intermediates.

Scheme 4. Proposed catalytic cycle for the regioselective alkyne hydrothiolation leading to branched vinyl sulfides.

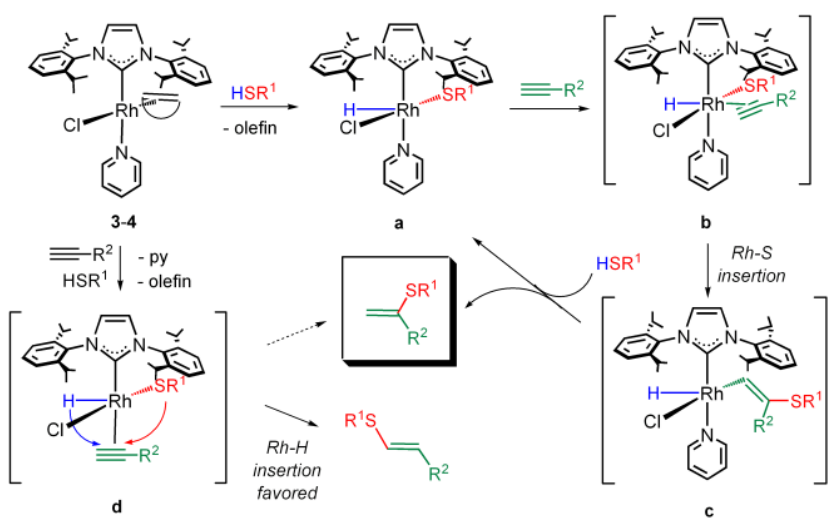

Consequently, a complex interplay between stereoelectronic properties of IPr, pyridine and hydride ligands accounts for the good-to-excellent regioselectivity achieved with these catalytic systems. It is likely that IPr and hydride direct pyridine coordination to the more favorable coordination site, that located trans to IPr. Alkyne is now forced to coordinate trans to hydride and so cis to thiolate favoring Markovnikov selectivity. The absence of pyridine allows the alkyne to coordinate in the preferred site trans to IPr position, and thus subsequent unselective migratory insertion takes place. This 
catalytic system is an example where pyridine plays an important role as additive in a transition-metal mediated catalytic transformation. ${ }^{47}$ The "pyridine effect" in this system has been rationalized with a molecular basis and it is further supported by theoretical calculations.

Theoretical calculations on the reaction mechanism. To gain more insight about the feasibility of our proposed mechanism, theoretical calculations on the catalytic cycle were performed for phenylacetylene and thiophenol (DFT, B3LYP, kcal mol ${ }^{-1}$, Figure 8). As far as we know, theoretical studies dealing with alkyne hydrothiolation or insertion of an alkyne into metal-thiolate bonds are scarce. ${ }^{13 \mathrm{~d}, 48}$ Calculations of the involved organometallic intermediates were performed without any simplifying approximation in order to increase accuracy of the results. The starting point is the square-pyramidal thiolate-hydride species 11a (Figure 5) and phenylacetylene. In 11a only migratory insertion of the alkyne into rhodiumthiolate is possible but discrimination between migration into $\alpha$ or $\beta$ carbon atoms of the alkyne determines the configuration of the final product. Thus, both pathways for the insertion of thiol were calculated. The red line shows the 1,2-insertion or Markovnikov addition pathway (a) whereas the blue line corresponds to the 2,1-insertion or anti-Markovnikov route (b) (Figure 8 ). Complete energy profile shows that the reaction is kinetically determined by the migratory insertion step as the highest hurdle. In accordance with the experimental results, the formation of branched vinyl sulfides obtained via Markovnikov pathway is favored. The possibility of migratory insertion of the alkyne into the rhodium-hydride bond has been also calculated. In agreement with our mechanistic proposal the transition states for both insertion types are higher in energy than TSIa $\left(25.9\right.$ and $27.7 \mathrm{kcal} \mathrm{mol}^{-1}$, see Supporting Information for details).

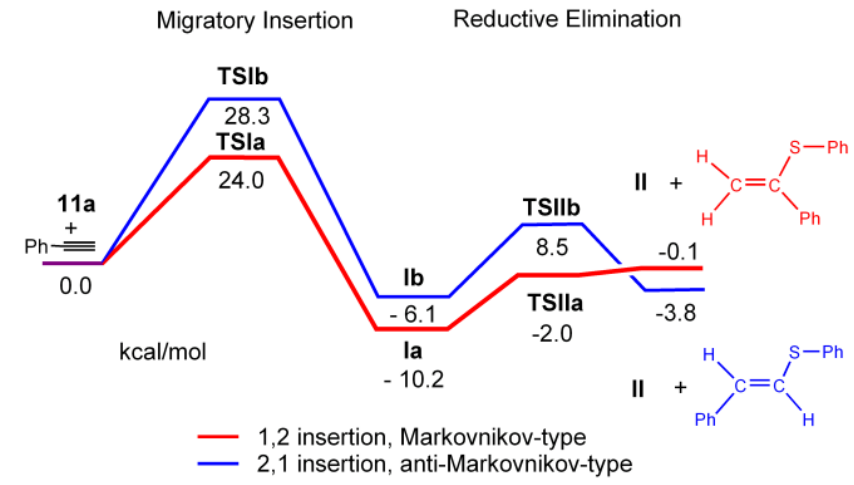

Figure 8. Computed potential-energy profile for the alkyne migratory insertion and reductive elimination for the formation of vinyl sulfide.

It has been determined that the coordination of the alkyne to 11a is hindered by sterical means, thus a stationary point for the saturated species similar to b (Scheme 4) was not found for either alkyne orientation. However, we were able to locate the transition states corresponding to $\mathrm{C}-\mathrm{S}$ and $\mathrm{Rh}-\mathrm{C}$ coupling for both pathways (TSIa and TSIb). An affordable value of $24.0 \mathrm{kcal} \mathrm{mol}^{-1}$ was computed for 1,2 insertion TSIa which is $4.3 \mathrm{kcal} \mathrm{mol}^{-1}$ lower in energy than TSIb. Either transition state displays a roughly metalacyclobutene structure including the metal, sulfur and the two carbon atoms of the former alkyne (Figure 9). Rhodium-thiolate and C-C bonds slightly elongate from $2.355 \AA$ in 11a and $1.210 \AA$ in phenylacetylene to $2.414 \AA$ (Rh-S) and $1.276 \AA(\mathrm{C}-\mathrm{C})$ in TSIa and $2.399 \AA$ $(\mathrm{Rh}-\mathrm{S})$ and $1.260 \AA$ (C-C) in TSIb.

Intermediates Ia and Ib bearing a thioalkenyl ligand, similar to proposed species c, were found to be -10.2 and $-6.1 \mathrm{kcal}$ $\mathrm{mol}^{-1}$ more stable than the starting point. The new $\mathrm{Rh}-\mathrm{C}$ bond formed agrees with typical simple bond distances, $2.007 \AA$ in Ia and $2.010 \AA$ in Ib. In the reductive elimination step, two new transition states were located at $8.5 \mathrm{kcal} \mathrm{mol}^{-1}$ (TSIIb) and $-2.0 \mathrm{kcal} \mathrm{mol}^{-1}$ (TSIIa) being again the anti-Markovnikov pathway unfavorable. The final point corresponding to the unsaturated species $\mathrm{RhCl}(\mathrm{IPr})$ II and the respective coupled organic products is slightly more favorable for the formation of linear vinyl sulfides $\left(-3.8 \mathrm{vs}-0.1 \mathrm{kcal} \mathrm{mol}^{-1}\right)$ although both pathways are thermodynamically less energetic that the starting point. 


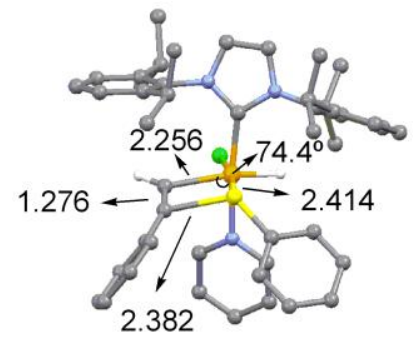

TSla

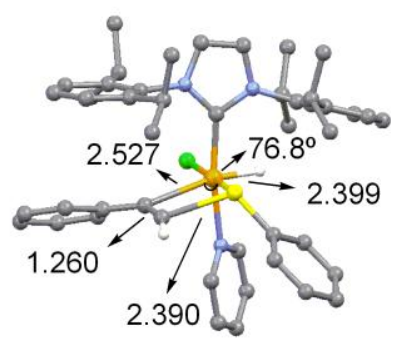

TSIb

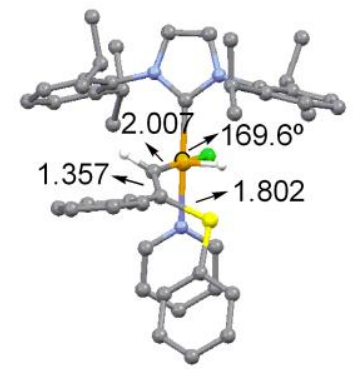

la

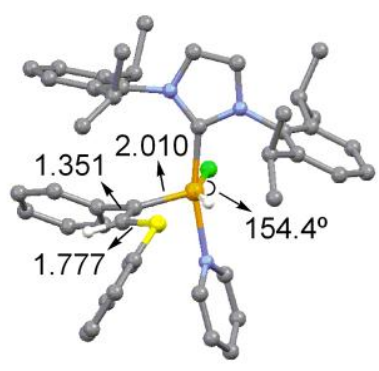

lb

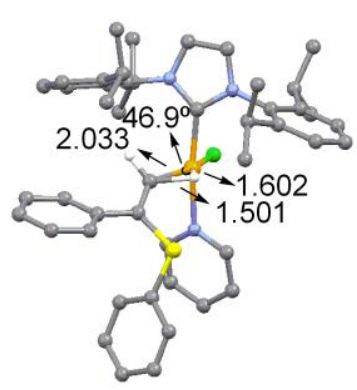

TSIla

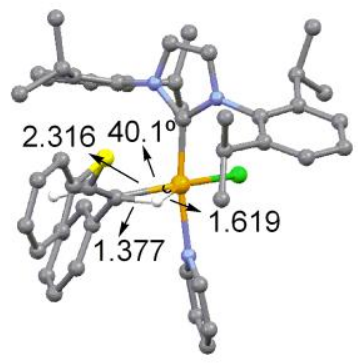

TSIIb

Figure 9. Optimized structures for the intermediates and transition states for migratory insertion and reductive elimination steps including selected distances $(\AA)$ and angles (deg).

\section{CONCLUSION}

Herein we have presented highly active Rh-NHC catalysts for alkyne hydrothiolation under mild conditions. Pyridinetype ligands easily cleave the chloro-bridges in dinuclear derivatives $\left[\mathrm{Rh}(\mu-\mathrm{Cl})(\mathrm{IPr})\left(\eta^{2} \text {-olefin }\right)\right]_{2}$ to afford stable mononuclear complexes $\mathrm{RhCl}(\mathrm{IPr})(\mathrm{L})\left(\eta^{2}\right.$-coe). The presence of a powerful electron-donor bulky IPr ligand prevents deactivation of active species thus increasing catalytic activity compared to $\mathrm{RhCl}\left(\mathrm{PPh}_{3}\right)_{3}$. It has been found that dinuclear complexes are more active than their related pyridine mononuclear complexes. However, a reversion in the regioselectivity from $\beta$ - $E$ to $\alpha$ was observed with mononuclear catalysts compared to dinuclear precursors.

It has been also determined that the mechanism proceeds via oxidative-addition of the $\mathrm{S}-\mathrm{H}$ bond to $\mathrm{Rh}^{\mathrm{I}}$ intermediates and successive alkyne migratory insertion and reductive elimination steps. The regioselectivity of the catalytic outcome is determined by the alkyne migratory insertion into the Rh-S bond. The interplay of electronic and steric effects exerted by IPr, pyridine and hydride ligands accounts for the regioselective formation of branched vinyl sulfides as a consequence of the 1,2-insertion into the rhodium-thiolate bond. The encumbered and powerful electron donor NHC ligand directs the coordination of the pyridine trans to it, consequently blocking the coordination of the alkyne in this position. Simultaneously, the trans influence of the hydride paves the way to a cis thiolate-alkyne disposition that gives rise to the branched vinyl sulfide regioisomer. This mechanistic proposal is supported by DFT quantum-mechanical calculations. The rate-determining step is the alkyne migratory insertion leading to the C-S bond formation. The energy difference of $4.3 \mathrm{kcal}$ $\mathrm{mol}^{-1}$ favoring the 1,2 over the 2,1-migratory insertion fully account for the observed regioselectivity.

The findings reported herein could be useful for the rational molecular design of new catalysts with improved regioselectivity in related addition processes such as hydroalkoxylation, hydrophosphination, hydroamination or hidroacylation among others. With the aim to improve activity and selectivity, catalysts design by modification of both NHC and ancillary ligands is currently investigated in our laboratories.

\section{EXPERIMENTAL SECTION}

General considerations. All reactions were carried out with rigorous exclusion of air using Schlenk-tube techniques. Organic solvents were dried by standard procedures and distilled under argon prior to use or obtained oxygen- and water-free from a Solvent Purification System (Innovative Technologies). The starting material $[\mathrm{Rh}(\mu-\mathrm{Cl})(\mathrm{IPr})(\mathrm{coe})]_{2}$ (1) was prepared as previously described in the literature. ${ }^{31 b}{ }^{1} \mathrm{H},{ }^{13} \mathrm{C}\left\{{ }^{1} \mathrm{H}\right\}$, and ${ }^{19} \mathrm{~F}$ NMR spectra were recorded on either a Varian Gemini 2000, a Bruker ARX $300 \mathrm{MHz}$ a Bruker Avance $400 \mathrm{MHz}$ or a Bruker Avance $500 \mathrm{MHz}$ instrument. Chemical shifts (expressed in parts per million) are referenced to residual solvent peaks $\left({ }^{1} \mathrm{H}\right.$, $\left.{ }^{13} \mathrm{C}\left\{{ }^{1} \mathrm{H}\right\}\right)$ or external $\mathrm{CFCl}_{3}\left({ }^{19} \mathrm{~F}\right)$. Coupling constants, $J$, are given in hertz. Spectral assignments were achieved by combination of ${ }^{1} \mathrm{H}-{ }^{1} \mathrm{H}$ COSY, ${ }^{13} \mathrm{C}$ APT and ${ }^{1} \mathrm{H}^{13} \mathrm{C}$ HSQC/HMBC experiments. $\mathrm{C}, \mathrm{H}$, and $\mathrm{N}$ analyses were carried out in a Perkin-Elmer $2400 \mathrm{CHNS/O}$ analyzer. GC-MS analysis were run on an Agilent 5973 mass selective detector interfaced to an 
Agilent 6890 series gas chromatograph system, using a HP5MS 5\% phenyl methyl siloxane column (30 m x $250 \mu \mathrm{m}$ with a $0.25 \mu \mathrm{m}$ film thickness).

Preparation of $\left[\mathrm{Rh}(\mu-\mathrm{Cl})(\mathrm{IPr})\left(\eta^{2}-\mathrm{CH}_{2}=\mathrm{CH}_{2}\right)\right]_{2}$ (2). A yellow solution of $1(300 \mathrm{mg}, 0.236 \mathrm{mmol})$ in $10 \mathrm{~mL}$ of toluene at room temperature was bubbled with ethylene for $15 \mathrm{~min}$. Then, the solvent was evaporated to dryness and subsequent addition of hexane caused the precipitation of a yellow solid which was washed with hexane $(3 \times 4 \mathrm{~mL})$ and dried in vacuo. Yield: $240 \mathrm{mg}(92 \%)$. Anal. Calcd. for $\mathrm{C}_{58} \mathrm{H}_{80} \mathrm{~N}_{4} \mathrm{Cl}_{2} \mathrm{Rh}_{2}: \mathrm{C}$, 62.76; H, 7.26; N, 5.05. Found: C, 62.45; H, 7.15; N, 4.94. ${ }^{1} \mathrm{H}$ NMR $\left(300 \mathrm{MHz}\right.$, tol- $\left.d_{8}, 233 \mathrm{~K}\right): \delta 7.3-7.1\left(\mathrm{~m}, 12 \mathrm{H}, \mathrm{H}_{\mathrm{Ph}-\mathrm{IPr}}\right)$, $6.19(\mathrm{~s}, 4 \mathrm{H},=\mathrm{CHN}), 3.27$ and 2.90 (both sept, $J_{\mathrm{H}-\mathrm{H}}=6.6,8 \mathrm{H}$, $\mathrm{CHMe}_{\mathrm{IPr}}$ ), 2.84 and 2.27 (both d, $J_{\mathrm{H}-\mathrm{H}}=12.6,8 \mathrm{H}, \mathrm{CH}_{2}=\mathrm{CH}_{2}$ ), $1.62,1.47,1.00$, and 0.96 (all d, $J_{\mathrm{H}-\mathrm{H}}=6.6,48 \mathrm{H}, \mathrm{CHMe}_{\mathrm{IPr}}$ ). ${ }^{13} \mathrm{C}\left\{{ }^{1} \mathrm{H}\right\}$-APT NMR plus HSQC and HMBC (75.4 MHz, tol$\left.d_{8}, 233 \mathrm{~K}\right): \delta 179.7\left(\mathrm{~d}, J_{\mathrm{C}-\mathrm{Rh}}=62.3, \mathrm{Rh}-\mathrm{C}_{\mathrm{IPr}}\right), 146.2$ and 145.2 (both s, $\mathrm{C}_{\mathrm{q}}$ ), $137.0\left(\mathrm{~s}, \mathrm{C}_{\mathrm{q}} \mathrm{N}\right), 129.1$ and $123.6\left(\mathrm{~s}, \mathrm{CH}_{\mathrm{Ph}-\mathrm{IPr}}\right)$, $123.7(\mathrm{~s},=\mathrm{CHN}), 43.4\left(\mathrm{~d}, J_{\mathrm{C}-\mathrm{Rh}}=16.7, \mathrm{CH}_{2}=\mathrm{CH}_{2}\right), 28.5(\mathrm{~s}$,

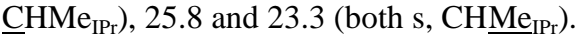

Preparation of $\operatorname{RhCl(IPr})\left(\eta^{2}\right.$-coe)(py) (3). A yellow solution of 1 (300 mg, $0.236 \mathrm{mmol})$ in $10 \mathrm{~mL}$ of toluene was treated with pyridine $(200 \mu \mathrm{l}, 2.47 \mathrm{mmol})$ and stirred at room temperature for $15 \mathrm{~min}$. Then, the solvent was evaporated to dryness and subsequent addition of hexane caused the precipitation of a yellow solid which was washed with hexane $(3 \times 4$ $\mathrm{mL})$ and dried in vacuo. Yield: $280 \mathrm{mg}(83 \%)$. Anal. Calcd. for $\mathrm{C}_{40} \mathrm{H}_{55} \mathrm{~N}_{3} \mathrm{ClRh}$ : $\mathrm{C}, 67.07 ; \mathrm{H}, 7.73 ; \mathrm{N}, 5.87$. Found: $\mathrm{C}$, 66.83; H, 7.55; N, 6.02. ${ }^{1} \mathrm{H}$ NMR (300 MHz, $\left.\mathrm{C}_{6} \mathrm{D}_{6}, 298 \mathrm{~K}\right): \delta$ $8.40\left(\mathrm{~d}, J_{\mathrm{H}-\mathrm{H}}=4.3,2 \mathrm{H}, \mathrm{H}_{2-\mathrm{Py}}\right), 7.4-7.2\left(\mathrm{~m}, 6 \mathrm{H}, \mathrm{H}_{\mathrm{Ph}-\mathrm{IPr}}\right), 6.64(\mathrm{~s}$, $2 \mathrm{H},=\mathrm{CHN}), 6.55\left(\mathrm{t}, J_{\mathrm{H}-\mathrm{H}}=5.4,1 \mathrm{H}, \mathrm{H}_{4-\mathrm{Py}}\right), 6.20\left(\mathrm{dd}, J_{\mathrm{H}-\mathrm{H}}=\right.$ $5.4, J_{\mathrm{H}-\mathrm{H}}=4.3,2 \mathrm{H}, \mathrm{H}_{3-P y}$ ), 4.52 and 2.61 (both sept, $J_{\mathrm{H}-\mathrm{H}}=6.4$, $\left.4 \mathrm{H}, \underline{\mathrm{CHMe}}_{\mathrm{IPr}}\right), 3.12\left(\mathrm{~m}, 2 \mathrm{H}, \mathrm{CH}=\mathrm{CH}_{\text {coe }}\right), 1.81,1.47,1.15$, and $1.02\left(\right.$ all d, $\left.J_{\mathrm{H}-\mathrm{H}}=6.4,24 \mathrm{H}, \mathrm{CHMe}_{\mathrm{IPr}}\right), 1.8-0.8\left(\mathrm{br}, 12 \mathrm{H}, \mathrm{CH}_{2}\right.$ coe). ${ }^{13} \mathrm{C}\left\{{ }^{1} \mathrm{H}\right\}$-APT NMR plus HSQC and HMBC $(75.6 \mathrm{MHz}$, $\left.\mathrm{C}_{6} \mathrm{D}_{6}, 253 \mathrm{~K}\right): \delta 183.3\left(\mathrm{~d}, J_{\mathrm{C}-\mathrm{Rh}}=54.0, \mathrm{Rh}-\mathrm{C}_{\mathrm{IPr}}\right), 153.9\left(\mathrm{~s}, \mathrm{C}_{2-}\right.$ Py), 149.3 and 146.6 (both s, $\mathrm{C}_{\mathrm{q}}$ ), $138.3\left(\mathrm{~s}, \mathrm{C}_{\mathrm{q}} \mathrm{N}\right), 135.1\left(\mathrm{~s}, \mathrm{C}_{4-}\right.$ Py), 129.7, 128.9, 125.5, and 123.1 (all s, $\left.\mathrm{CH}_{\mathrm{Ph}-\mathrm{PPr}}\right), 124.8$ (s, $=\mathrm{CHN}), 122.9\left(\mathrm{~s}, \mathrm{C}_{3-\mathrm{Py}}\right), 56.1\left(\mathrm{~d}, J_{\mathrm{C}-\mathrm{Rh}}=16.4, \mathrm{CH}=\mathrm{CH}_{\mathrm{coe}}\right)$, 30.6, 30.4, and 27.3 (all s, $\mathrm{CH}_{2 \text {-coe }}$ ), 29.5 and 29.4 (both s,

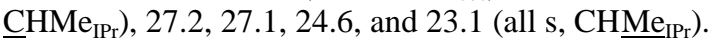

Preparation of $\mathrm{RhCl}(\mathrm{IPr})\left(\eta^{2}-\mathrm{CH}_{2}=\mathrm{CH}_{2}\right)(\mathrm{py})$ (4). The complex was prepared as described for $\mathbf{3}$ starting for $\mathbf{2}$ (300 $\mathrm{mg}, 0.270 \mathrm{mmol})$ and pyridine $(220 \mu \mathrm{l}, 2.72 \mathrm{mmol})$. Yield: 290 mg (85\%). Anal. Calcd. for $\mathrm{C}_{34} \mathrm{H}_{45} \mathrm{~N}_{3} \mathrm{ClRh}$ : C, 64.40; H, 7.15; $\mathrm{N}, 6.63$. Found: $\mathrm{C}, 64.22 ; \mathrm{H}, 7.02 ; \mathrm{N}, 6.45 .{ }^{1} \mathrm{H}$ NMR $(500$ $\mathrm{MHz}$, tol- $\left.d_{8}, 253 \mathrm{~K}\right): \delta 8.32\left(\mathrm{~d}, J_{\mathrm{H}-\mathrm{H}}=4.5,2 \mathrm{H}, \mathrm{H}_{2-\mathrm{Py}}\right), 7.3-7.1$ $\left(\mathrm{m}, 6 \mathrm{H}, \mathrm{H}_{\mathrm{Ph}-\mathrm{Pr}}\right), 6.54(\mathrm{~s}, 2 \mathrm{H},=\mathrm{CHN}), 6.46\left(\mathrm{t}, J_{\mathrm{H}-\mathrm{H}}=5.5,1 \mathrm{H}\right.$, $\left.\mathrm{H}_{4-\mathrm{Py}}\right), 6.08\left(\mathrm{dd}, J_{\mathrm{H}-\mathrm{H}}=5.5, J_{\mathrm{H}-\mathrm{H}}=4.52 \mathrm{H}, \mathrm{H}_{3-\mathrm{Py}}\right), 4.09$ and 3.08 (both sept, $J_{\mathrm{H}-\mathrm{H}}=6.5,4 \mathrm{H}, \mathrm{CHMe}_{\mathrm{IPr}}$ ), 2.52 and 2.03 (both d, $J_{\mathrm{H}-}$ $\left.\mathrm{H}=11.5,4 \mathrm{H}, \mathrm{CH}_{2}=\mathrm{CH}_{2}\right), 1.91,1.57,1.23$, and 1.13 (all d, $J_{\mathrm{H}-\mathrm{H}}$ $\left.=6.5,24 \mathrm{H}, \mathrm{CHM} \underline{\mathrm{MPr}}_{\mathrm{IP}}\right) .{ }^{13} \mathrm{C}\left\{{ }^{1} \mathrm{H}\right\}$-APT NMR plus HSQC and HMBC $\left(125.6 \mathrm{MHz}\right.$, tol- $\left.d_{8}, 253 \mathrm{~K}\right): \delta 183.3\left(\mathrm{~d}, J_{\mathrm{C}-\mathrm{Rh}}=54.5\right.$, Rh- $\mathrm{C}_{\mathrm{IPr}}$ ), 151.5 (s, $\mathrm{C}_{2-\mathrm{Py}}$ ), 148.1 and 145.4 (both s, $\mathrm{C}_{\mathrm{q}}$ ), 137.4 $\left(\mathrm{s}, \mathrm{C}_{\mathrm{q}} \mathrm{N}\right.$ ), 134.5 (s, $\left.\mathrm{C}_{4-\mathrm{Py}}\right), 129.1,128.4,124.2$, and 122.7 (all s, $\left.\mathrm{CH}_{\mathrm{Ph}-\mathrm{IPr}}\right), 123.7(\mathrm{~s},=\mathrm{CHN}), 122.5\left(\mathrm{~s}, \mathrm{C}_{3-\mathrm{Py}}\right), 41.6\left(\mathrm{~d}, J_{\mathrm{C}-\mathrm{Rh}}=\right.$ 15.4, $\mathrm{CH}_{2}=\mathrm{CH}_{2}$ ), 28.9 and 28.7 (both s, $\underline{\mathrm{C}} \mathrm{HMe}_{\mathrm{IPr}}$ ), 26.3, 26.1, 23.9, and 22.9 (all s, $\mathrm{CHMe} \underline{\mathrm{IPr}}_{\text {) }}$ ).
Preparation of $\mathrm{RhCl}(\mathrm{IPr})\left(\eta^{2}\right.$-coe)(2-picoline) (5). The complex was prepared as described for $\mathbf{3}$ starting for $\mathbf{1}$ (300 $\mathrm{mg}, 0.236 \mathrm{mmol})$ and 2-picoline $(230 \mu \mathrm{l}, 2.329 \mathrm{mmol})$. Yield: $275 \mathrm{mg}(80 \%)$. Anal. Calcd. for $\mathrm{C}_{41} \mathrm{H}_{57} \mathrm{~N}_{3} \mathrm{ClRh}$ : C, 67.43; H, 7.87; N, 5.75. Found: C, 67.74; H, 7.91; N, 5.68. ${ }^{1} \mathrm{H}$ NMR $\left(300 \mathrm{MHz}, \mathrm{C}_{6} \mathrm{D}_{6}, 293 \mathrm{~K}\right): \delta 8.43\left(\mathrm{~d}, J_{\mathrm{H}-\mathrm{H}}=5.2,1 \mathrm{H}, \mathrm{H}_{6-\mathrm{Py}}\right)$, 7.49-7.11 (m, $\left.6 \mathrm{H}, \mathrm{H}_{\mathrm{Ph}-\mathrm{IPr}}\right), 6.71$ and 6.61 (both d, $J_{\mathrm{H}-\mathrm{H}}=1.4$, $2 \mathrm{H},=\mathrm{CHN}), 6.57\left(\mathrm{dd}, J_{\mathrm{H}-\mathrm{H}}=7.9, J_{\mathrm{H}-\mathrm{H}}=7.6,1 \mathrm{H}, \mathrm{H}_{4-\mathrm{Py}}\right), 6.34$ $\left(\mathrm{d}, J_{\mathrm{H}-\mathrm{H}}=7.6,1 \mathrm{H}, \mathrm{H}_{3-\mathrm{Py}}\right), 6.21\left(\mathrm{dd}, J_{\mathrm{H}-\mathrm{H}}=7.9, J_{\mathrm{H}-\mathrm{H}}=5.2,1 \mathrm{H}\right.$, $\mathrm{H}_{5-\mathrm{Py}}$ ), 4.96, 4.16, 2.83 and 2.20 (all sept, $J_{\mathrm{H}-\mathrm{H}}=6.4,4 \mathrm{H}$, $\left.\mathrm{CHMe}_{\mathrm{IPr}}\right), 3.07\left(\mathrm{~m}, 2 \mathrm{H}, \mathrm{CH}=\mathrm{CH}_{\text {coe }}\right), 2.75\left(\mathrm{~s}, 3 \mathrm{H}, \mathrm{H}_{\mathrm{CH} 3-\mathrm{Py}}\right)$, $1.97,1.65,1.49,1.33,1.22,1.11,1.07$ and $0.94\left(\right.$ all d, $J_{\mathrm{H}-\mathrm{H}}=$ 6.4, 24H, CHMe ${ }_{\text {IPr }}$ ), 1.8-0.8 (br, $12 \mathrm{H}, \mathrm{CH}_{2-\text { coe }}$ ). ${ }^{13} \mathrm{C}\left\{{ }^{1} \mathrm{H}\right\}-\mathrm{APT}$ NMR plus HSQC and HMBC (75.6 MHz, $\left.\mathrm{C}_{6} \mathrm{D}_{6}, 293 \mathrm{~K}\right): \delta$ $185.7\left(\mathrm{~d}, J_{\mathrm{C}-\mathrm{Rh}}=53.5, \mathrm{Rh}-\mathrm{C}_{\mathrm{IPr}}\right), 162.1\left(\mathrm{~s}, \mathrm{C}_{2-\mathrm{Py}}\right), 153.0\left(\mathrm{~s}, \mathrm{C}_{6-\mathrm{Py}}\right)$, 149.7, 149.4, 146.9 and 146.7 (all s, $\mathrm{C}_{\mathrm{q}}$ ), 138.5, 138.0 (both, $\left.\mathrm{C}_{\mathrm{q}} \mathrm{N}\right), 135.0\left(\mathrm{~s}, \mathrm{C}_{4-\mathrm{Py}}\right), 130.1,129.9,126.0,125.5$, and 123.4, 122.9 (all s, $\mathrm{CH}_{\mathrm{Ph}-\mathrm{IPr}}$ ), 125.2 and 124.9 (both s, =CHN), 124.6 $\left(\mathrm{s}, \mathrm{C}_{3-\mathrm{Py}}\right), 119.9$ (s, $\mathrm{C}_{5-\mathrm{Py}}$ ), 58.3, 52.5 (both d, $J_{\mathrm{C}-\mathrm{Rh}}=16.3$, $\mathrm{CH}=\mathrm{CH}_{\text {coe }}$ ), 31.3, 30.0, 29.4, 29.3, 27.4, and $27.2\left(\right.$ all s, $\mathrm{CH}_{2}$ coe), 29.9, 29.7, 29.2 and 29.0 (all s, $\mathrm{CHMe}_{\mathrm{IPr}}$ ), 27.9, 27.3, 27.1, 26.7, 25.0, 24.1, 23.5, and 22.5 (all s, $\mathrm{CHMe} \underline{\mathrm{MPr}}_{\mathrm{IP}}$ ), 26.9 (s, $\left.\mathrm{C}_{\mathrm{CH} 3-\mathrm{Py}}\right)$.

Preparation of $\mathrm{RhCl}(\mathrm{IPr})\left(\eta^{2}-\mathrm{CH}_{2}=\mathrm{CH}_{2}\right)$ (2-picoline) (6). The complex was prepared as described for $\mathbf{3}$ starting for 2 $(300 \mathrm{mg}, 0.270 \mathrm{mmol})$ and 2-picoline $(270 \mu \mathrm{l}, 2.734 \mathrm{mmol})$. Yield: $270 \mathrm{mg}(77 \%)$. Anal. Calcd. for $\mathrm{C}_{35} \mathrm{H}_{47} \mathrm{~N}_{3} \mathrm{ClRh}$ : C, 64.86; H, 7.31; N, 6.48. Found: C, 65.01; H, 7.45; N, 6.37. ${ }^{1} \mathrm{H}$ NMR $\left(500 \mathrm{MHz}\right.$, tol- $\left.d_{8}, 253 \mathrm{~K}\right): \delta 8.21\left(\mathrm{~d}, J_{\mathrm{H}-\mathrm{H}}=5.3,1 \mathrm{H}, \mathrm{H}_{6-}\right.$ Py), 7.37-7.09 (m, 6H, $\left.\mathrm{H}_{\mathrm{Ph}-\mathrm{IPr}}\right), 6.59$ and 6.49 (both $\mathrm{d}, J_{\mathrm{H}-\mathrm{H}}=$ $1.6,2 \mathrm{H},=\mathrm{CHN}), 6.47\left(\mathrm{dd}, J_{\mathrm{H}-\mathrm{H}}=8.0, J_{\mathrm{H}-\mathrm{H}}=7.7,1 \mathrm{H}, \mathrm{H}_{4-p y}\right)$, $6.14\left(\mathrm{~d}, J_{\mathrm{H}-\mathrm{H}}=7.7,1 \mathrm{H}, \mathrm{H}_{3-\mathrm{Py}}\right), 5.93\left(\mathrm{dd}, J_{\mathrm{H}-\mathrm{H}}=8.0, J_{\mathrm{H}-\mathrm{H}}=5.3\right.$, $1 \mathrm{H}, \mathrm{H}_{5-\mathrm{Py}}$ ), 4.32, 4.05, 3.05 and 2.59 (all sept, $J_{\mathrm{H}-\mathrm{H}}=6.7,4 \mathrm{H}$, $\mathrm{CHMe}_{\mathrm{IPr}}$ ), 2.58 (s, 3H, $\mathrm{H}_{\mathrm{CH} 3-\mathrm{Py}}$ ), 2.56, 2.35, 2.04 and 1.64 (all $\left.\mathrm{dd}, J_{\mathrm{H}-\mathrm{H}}=11.7, J_{\mathrm{H}-\mathrm{H}}=8.8,4 \mathrm{H}, \mathrm{CH}_{2}=\mathrm{CH}_{2}\right), 1.94,1.70,1.49$, $1.40,1.21,1.13,1.10$ and 1.02 (all d, $J_{\mathrm{H}-\mathrm{H}}=6.7,24 \mathrm{H}$, $\left.\mathrm{CHMe}_{\mathrm{IPr}}\right) .{ }^{13} \mathrm{C}\left\{{ }^{1} \mathrm{H}\right\}$-APT NMR plus HSQC and HMBC (125.6 $\mathrm{MHz}$, tol- $\left.d_{8}, 293 \mathrm{~K}\right): \delta 184.9\left(\mathrm{~d}, J_{\mathrm{C}-\mathrm{Rh}}=53.8, \mathrm{Rh}-\mathrm{C}_{\mathrm{IPr}}\right), 160.9$ (s, $\mathrm{C}_{2-\mathrm{Py}}$ ), 151.7 (s, $\mathrm{C}_{6-\mathrm{Py}}$ ), 149.5 and 147.2 (both s, $\mathrm{C}_{\mathrm{q}}$ ), 137.4 $\left(\mathrm{s}, \mathrm{C}_{\mathrm{q}} \mathrm{N}\right), 134.7$ (s, $\left.\mathrm{C}_{4-\mathrm{Py}}\right), 129.1,128.4,125.4$, and 122.8 (all s, $\mathrm{CH}_{\mathrm{Ph}-\mathrm{IPr}}$ ), 124.1 (s, $\left.\mathrm{C}_{3-\mathrm{Py}}\right), 123.9(\mathrm{~s},=\mathrm{CHN}), 120.5$ (s, $\mathrm{C}_{5-\mathrm{Py}}$ ), $43.7\left(\mathrm{~d}, J_{\mathrm{C}-\mathrm{Rh}}=16.6, \mathrm{CH}_{2}=\mathrm{CH}_{2}\right), 25.4\left(\mathrm{~s}, \mathrm{C}_{\mathrm{CH} 3-\mathrm{Py}}\right), 29.1$ and 28.9 (both s, $\underline{\mathrm{CHMe}} \mathrm{IPr}$ ), 26.6, 26.1, 23.7, and 23.2 (all s, $\mathrm{CHMe}_{\text {IPr }}$ ).

Preparation of $\mathbf{R h C l}(\mathrm{IPr})\left(\eta^{2}\right.$-coe)(4-picoline) (7). The complex was prepared as described for $\mathbf{3}$ starting for 1 (300 $\mathrm{mg}, 0.236 \mathrm{mmol})$ and 4-picoline (230 $\mu \mathrm{l}, 2.329 \mathrm{mmol})$. Yield: $280 \mathrm{mg}$ (81\%). Anal. Calcd. for $\mathrm{C}_{41} \mathrm{H}_{57} \mathrm{~N}_{3} \mathrm{ClRh}$ : C, 67.43; H, 7.87; N, 5.75. Found: C, 67.81; H, 7.98; N, 5.87. ${ }^{1} \mathrm{H}$ NMR $\left(300 \mathrm{MHz}\right.$, tol- $\left.d_{8}, 253 \mathrm{~K}\right): \delta 8.22\left(\mathrm{~d}, J_{\mathrm{H}-\mathrm{H}}=5.7,2 \mathrm{H}, \mathrm{H}_{2-\mathrm{Py}}\right)$, $7.42-6.97\left(\mathrm{~m}, 6 \mathrm{H}, \mathrm{H}_{\mathrm{Ph}-\mathrm{IPr}}\right), 6.65(\mathrm{~s}, 2 \mathrm{H},=\mathrm{CHN}), 6.08\left(\mathrm{~d}, J_{\mathrm{H}-\mathrm{H}}=\right.$ $5.7,2 \mathrm{H}, \mathrm{H}_{2-\mathrm{Py}}$ ), 4.46 and 2.61 (both sept, $J_{\mathrm{H}-\mathrm{H}}=6.3,4 \mathrm{H}$, $\left.\mathrm{CHMe}_{\mathrm{IPr}}\right), 3.05\left(\mathrm{~m}, 2 \mathrm{H}, \mathrm{CH}=\mathrm{CH}_{\text {coe }}\right), 1.75,1.46,1.14$, and 1.03 (all d, $\left.J_{\mathrm{H}-\mathrm{H}}=6.3,24 \mathrm{H}, \mathrm{CHMe}_{\mathrm{IPr}}\right), 1.7-0.8\left(\mathrm{br}, 12 \mathrm{H}, \mathrm{CH}_{2 \text {-coe }}\right.$ ), $1.50\left(\mathrm{~s}, 3 \mathrm{H}, \mathrm{H}_{\mathrm{CH}-\mathrm{Py}}\right) .{ }^{13} \mathrm{C}\left\{{ }^{1} \mathrm{H}\right\}-\mathrm{APT}$ NMR plus HSQC and HMBC $\left(75.6 \mathrm{MHz}\right.$, tol- $\left.d_{8}, 253 \mathrm{~K}\right): \delta 185.8\left(\mathrm{~d}, J_{\mathrm{C}-\mathrm{Rh}}=53.9\right.$, Rh$\mathrm{C}_{\mathrm{IPr}}$ ), $153.0\left(\mathrm{~s}, \mathrm{C}_{2-\mathrm{Py}}\right), 149.1$ and 146.1 (both $\mathrm{s}, \mathrm{C}_{\mathrm{q}}$ ), 146.2 (s, $\mathrm{C}_{4-\mathrm{Py}}$ ), $138.0\left(\mathrm{~s}, \mathrm{C}_{\mathrm{q}} \mathrm{N}\right), 129.7,128.5,125.0$, and 122.7 (all s, $\left.\mathrm{CH}_{\mathrm{Ph}-\mathrm{IPr}}\right), 124.4(\mathrm{~s},=\mathrm{CHN}), 123.5\left(\mathrm{~s}, \mathrm{C}_{3-\mathrm{Py}}\right), 55.4\left(\mathrm{~d}, J_{\mathrm{C}-\mathrm{Rh}}=\right.$ 16.5, $\mathrm{CH}=\mathrm{CH}_{\text {coe }}$ ), 30.3, 30.0, and 27.0 (all s, $\mathrm{CH}_{2 \text {-coe }}$ ), 29.1 and 
29.0 (both s, $\underline{\mathrm{C} H M \mathrm{IPr}_{\mathrm{IP}}}$ ), 26.8, 26.7, 24.1, and 22.8 (all s, $\left.\mathrm{CHMe}_{\mathrm{IPr}}\right), 20.2\left(\mathrm{~s}, \mathrm{CH}_{3-\mathrm{Py}}\right)$.

Preparation of $\mathrm{RhCl}(\mathrm{IPr})\left(\eta^{2}-\mathrm{CH}_{2}=\mathrm{CH}_{2}\right)$ (4-picoline) (8). The complex was prepared as described for $\mathbf{3}$ starting for $\mathbf{2}$ (300 mg, $0.270 \mathrm{mmol})$ and 4-picoline $(270 \mu \mathrm{l}, 2.734 \mathrm{mmol})$. Yield: $277 \mathrm{mg}$ (79\%). Calcd. for $\mathrm{C}_{35} \mathrm{H}_{47} \mathrm{~N}_{3} \mathrm{ClRh}$ : C, 64.86; $\mathrm{H}$, 7.31; N, 6.48. Found: C, 65.15; H, 7.45; N, 6.52. ${ }^{1} \mathrm{H}$ NMR $\left(400 \mathrm{MHz}, \mathrm{C}_{6} \mathrm{D}_{6}, 298 \mathrm{~K}\right): \delta 8.23\left(\mathrm{~d}, J_{\mathrm{H}-\mathrm{H}}=6.0,2 \mathrm{H}, \mathrm{H}_{2-\mathrm{Py}}\right)$, 7.34-7.00 (m, 6H, $\left.\mathrm{H}_{\mathrm{Ph}-\mathrm{IPr}}\right), 6.60(\mathrm{~s}, 2 \mathrm{H},=\mathrm{CHN}), 5.97\left(\mathrm{~d}, J_{\mathrm{H}-\mathrm{H}}=\right.$ 6.0, $2 \mathrm{H}, \mathrm{H}_{3-\mathrm{Py}}$ ), 4.11 and 3.14 (both br, $4 \mathrm{H}, \mathrm{CHMe}_{\mathrm{IPr}}$ ), 2.52 and 2.12 (both br, $4 \mathrm{H}, \mathrm{CH}_{2}=\mathrm{CH}_{2}$ ), 1.87-1.00 (br, 24H, $\mathrm{CHMe}$ 1.50 (s, 3H, $\left.\mathrm{H}_{\mathrm{CH} 3-\mathrm{Py}}\right) .{ }^{13} \mathrm{C}\left\{{ }^{1} \mathrm{H}\right\}$-APT NMR plus HSQC and HMBC $\left(100.6 \mathrm{MHz}, \mathrm{C}_{6} \mathrm{D}_{6}, 298 \mathrm{~K}\right): \delta 184.6\left(\mathrm{~d}, J_{\mathrm{C}-\mathrm{Rh}}=53.7\right.$, Rh- $\left.\mathrm{C}_{\mathrm{IPr}}\right), 151.8\left(\mathrm{~s}, \mathrm{C}_{2-\mathrm{Py}}\right), 147.4$ and $147.2\left(\mathrm{~s}, \mathrm{C}_{\mathrm{q}}\right), 146.8\left(\mathrm{~s}, \mathrm{C}_{4}\right.$ $\left.{ }_{P y}\right), 138.3\left(\mathrm{~s}, \mathrm{C}_{\mathrm{q}} \mathrm{N}\right), 130.1$ and 128.7 (all s, $\left.\mathrm{CH}_{\mathrm{Ph}-\mathrm{PPr}}\right), 124.8$ (s, $=\mathrm{CHN}), 124.7\left(\mathrm{~s}, \mathrm{C}_{3-\mathrm{Py}}\right), 42.1\left(\mathrm{~d}, J_{\mathrm{C}-\mathrm{Rh}}=16.9, \mathrm{CH}_{2}=\mathrm{CH}_{2}\right), 29.6$ and 29.4 (both s, $\underline{\mathrm{C}} \mathrm{HMe}_{\mathrm{IPr}}$ ), 26.8, 26.6, 24.1, 26.6 (both s, $\left.\mathrm{CHMe}_{\mathrm{IPr}}\right), 20.5$ (s, $\left.\overline{\mathrm{C}}_{\mathrm{CH} 3-\mathrm{Py}}\right)$.

Preparation of $\operatorname{RhCl}(\operatorname{IPr})\left(\eta^{2}\right.$-coe)(2-ethylpyridine) (9). The complex was prepared as described for $\mathbf{3}$ starting for $\mathbf{1}$ (300 $\mathrm{mg}, 0.236 \mathrm{mmol}$ ) and 2-ethylpyridine (270 $\mu \mathrm{l}, 2.36$ mmol). Yield: $285 \mathrm{mg}(81 \%)$. Anal. Calcd. for $\mathrm{C}_{42} \mathrm{H}_{59} \mathrm{~N}_{3} \mathrm{ClRh}$ : C, 67.78; H, 7.99; N, 5.65. Found: C, 68.19; H, 8.12; N, 5.82. ${ }^{1} \mathrm{H}$ NMR $\left(500 \mathrm{MHz}\right.$, tol- $\left.d_{8}, 253 \mathrm{~K}\right): \delta 8.43\left(\mathrm{~d}, J_{\mathrm{H}-\mathrm{H}}=5.3,1 \mathrm{H}\right.$, $\left.\mathrm{H}_{6-\mathrm{Py}}\right), 7.38-6.99\left(\mathrm{~m}, 6 \mathrm{H}, \mathrm{H}_{\mathrm{Ph}-\mathrm{IPr}}\right), 6.63\left(\mathrm{dd}, J_{\mathrm{H}-\mathrm{H}}=8.9, J_{\mathrm{H}-\mathrm{H}}=\right.$ $\left.7.8,1 \mathrm{H}, \mathrm{H}_{4-\mathrm{Py}}\right), 6.62$ and 6.54 (both $\mathrm{d}, J_{\mathrm{H}-\mathrm{H}}=1.4,2 \mathrm{H},=\mathrm{CHN}$ ), $6.39\left(\mathrm{~d}, J_{\mathrm{H}-\mathrm{H}}=7.8,1 \mathrm{H}, \mathrm{H}_{3-\mathrm{Py}}\right), 6.20\left(\mathrm{dd}, J_{\mathrm{H}-\mathrm{H}}=8.9, J_{\mathrm{H}-\mathrm{H}}=5.3\right.$, $1 \mathrm{H}, \mathrm{H}_{5-\mathrm{Py}}$ ), 4.93, 3.98, 3.11 and 2.90 (all sept, $J_{\mathrm{H}-\mathrm{H}}=6.6,4 \mathrm{H}$, $\mathrm{C}^{\mathrm{H}} \mathrm{Me}_{\mathrm{IPr}}$ ), 3.65 and 3.34 (both dq, $J_{\mathrm{H}-\mathrm{H}}=15.2, J_{\mathrm{H}-\mathrm{H}}=7.5,2 \mathrm{H}$, $\mathrm{CH}_{2-\mathrm{Py}}$ ), 3.07 and 2.94 (both br, $2 \mathrm{H}, \mathrm{CH}=\mathrm{CH}_{\text {coe }}$ ), 2.11, 2.02, $1.59,1.40,1.29,1.22,1.08$ and $0.92\left(\right.$ all d, $J_{\mathrm{H}-\mathrm{H}}=6.6,24 \mathrm{H}$, $\mathrm{CHMe}_{\mathrm{IPr}}$ ), 1.8-0.9 (br, $\left.12 \mathrm{H}, \mathrm{CH}_{2-\mathrm{coe}}\right), 1.03\left(\mathrm{dd}, J_{\mathrm{H}-\mathrm{H}}=7.5, J_{\mathrm{H}-\mathrm{H}}\right.$ $\left.=7.5,3 \mathrm{H}, \mathrm{CH}_{3-\mathrm{Py}}\right) \cdot{ }^{13} \mathrm{C}\left\{{ }^{1} \mathrm{H}\right\}$-APT NMR plus HSQC and HMBC (125.6 MHz, tol- $\left.d_{8}, 253 \mathrm{~K}\right): \delta 184.7\left(\mathrm{~d}, J_{\mathrm{C}-\mathrm{Rh}}=53.4\right.$, Rh- $\mathrm{C}_{\mathrm{IPr}}$ ), 166.3 (s, $\mathrm{C}_{2-\mathrm{Py}}$ ), 152.3 (s, $\mathrm{C}_{6-\mathrm{Py}}$ ), 148.7, 148.6, 146.2, and 146.1 (all s, $\mathrm{C}_{\mathrm{q}}$ ), 137.9 and 137.2 (both s, $\mathrm{C}_{\mathrm{q}} \mathrm{N}$ ), 134.8 (s, $\mathrm{C}_{4-\mathrm{Py}}$ ), 129.6, 129.4, 128.2, 125.6, 122.9, and 122.3 (all s, $\mathrm{CH}_{\mathrm{Ph}-\mathrm{IPr}}$ ), 124.4 and 123.9 (both $\left.\mathrm{s},=\mathrm{CHN}\right), 121.9\left(\mathrm{~s}, \mathrm{C}_{3-\mathrm{Py}}\right)$, $119.6\left(\mathrm{~s}, \mathrm{C}_{5-\mathrm{Py}}\right), 58.3,51.6$ (both d, $J_{\mathrm{C}-\mathrm{Rh}}=16.0, \mathrm{CH}=\mathrm{CH}_{\text {coe }}$ ), 32.9 (s, $\mathrm{CH}_{2-\mathrm{Py}}$ ), 30.9, 30.4, 29.5, 29.4, 26.8, and 26.7 (all s, $\mathrm{CH}_{2-\mathrm{coe}}$ ), 29.5, 29.2, 28.7 and 28.5 (all s, $\underline{\mathrm{C}} \mathrm{HMe}_{\mathrm{IPr}}$ ), 27.5, 26.6, 26.4, 26.2, 24.7, 23.5, 23.1 and 21.9 (all s, $\mathrm{CHMe}_{\mathrm{IPr}}$ ), 13.4 (s, $\left.\mathrm{CH}_{3-\mathrm{Py}}\right)$.

Preparation of $\mathrm{RhCl}(\mathrm{IPr})\left(\eta^{2-} \mathrm{CH}_{2}=\mathrm{CH}_{2}\right)$ (2-ethylpiridine) (10). The complex was prepared as described for 3 starting for 2 (300 mg, $0.270 \mathrm{mmol}$ ) and 2-ethylpyridine (310 $\mu \mathrm{l}, 2.71$ mmol). Yield: $315 \mathrm{mg}(86 \%)$. Anal. Calcd. for $\mathrm{C}_{37} \mathrm{H}_{53} \mathrm{~N}_{3} \mathrm{ClRh}$ : C, 65.53; H, 7.88; N, 6.20. Found: C, 65.89; H, 7.98; N, 6.33. ${ }^{1} \mathrm{H}$ NMR $\left(500 \mathrm{MHz}\right.$, tol- $\left.d_{8}, 253 \mathrm{~K}\right): \delta 8.27\left(\mathrm{~d}, J_{\mathrm{H}-\mathrm{H}}=5.1,1 \mathrm{H}\right.$, $\left.\mathrm{H}_{6-\mathrm{Py}}\right), 7.38-6.99\left(\mathrm{~m}, 6 \mathrm{H}, \mathrm{H}_{\mathrm{Ph}-\mathrm{IPr}}\right), 6.60$ and 6.47 (both d, $J_{\mathrm{H}-\mathrm{H}}=$ $1.5,2 \mathrm{H},=\mathrm{CHN}), 6.57\left(\mathrm{dd}, J_{\mathrm{H}-\mathrm{H}}=9.0, J_{\mathrm{H}-\mathrm{H}}=7.7,1 \mathrm{H}, \mathrm{H}_{4-\mathrm{Py}}\right)$, $6.27\left(\mathrm{~d}, J_{\mathrm{H}-\mathrm{H}}=7.7,1 \mathrm{H}, \mathrm{H}_{3-\mathrm{Py}}\right), 6.09\left(\mathrm{dd}, J_{\mathrm{H}-\mathrm{H}}=9.0, J_{\mathrm{H}-\mathrm{H}}=5.1\right.$, $1 \mathrm{H}, \mathrm{H}_{5-\mathrm{Py}}$ ) $, 4.42,3.94,3.15$ and 2.45 (all sept, $J_{\mathrm{H}-\mathrm{H}}=6.6,4 \mathrm{H}$, $\mathrm{C}_{\mathrm{H}} \mathrm{Me}_{\mathrm{IPr}}$ ), 3.60 and 3.06 (both dq, $J_{\mathrm{H}-\mathrm{H}}=15.1,, J_{\mathrm{H}-\mathrm{H}}=7.6$, $\left.2 \mathrm{H}, \mathrm{CH}_{2-\mathrm{Py}}\right), 2.62,2.31,2.04$ and $1.62\left(\right.$ all dd, $J_{\mathrm{H}-\mathrm{H}}=11.7, J_{\mathrm{H}-\mathrm{H}}$ $\left.=8.4,4 \mathrm{H}, \mathrm{CH}_{2}=\mathrm{CH}_{2}\right), 1.96,1.6,1.51,1.36,1.21,1.13,1.09$ and $1.01\left(\right.$ all d, $\left.J_{\mathrm{H}-\mathrm{H}}=6.6,24 \mathrm{H}, \mathrm{CHMe} \mathrm{IPr}_{\mathrm{Ir}}\right), 0.96\left(\mathrm{dd}, J_{\mathrm{H}-\mathrm{H}}=\right.$ 7.6, $\left.J_{\mathrm{H}-\mathrm{H}}=7.6,3 \mathrm{H}, \mathrm{CH}_{3-\mathrm{Py}}\right) .{ }^{13} \mathrm{C}\left\{{ }^{1} \mathrm{H}\right\}$-APT NMR plus HSQC and $\mathrm{HMBC}\left(125.6 \mathrm{MHz}\right.$, tol- $\left.d_{8}, 253 \mathrm{~K}\right): \delta 184.3\left(\mathrm{~d}, J_{\mathrm{C}-\mathrm{Rh}}=\right.$ 53.8, Rh-C $\mathrm{CPr}_{\text {IPr }}$ ), 165.5 (s, C 2 -Py $), 151.6\left(\mathrm{~s}, \mathrm{C}_{6-\mathrm{Py}}\right), 148.7,148.4$, 146.2, and 145.7 (all s, $\mathrm{C}_{\mathrm{q}}$ ), 137.6 and 137.2 (both $\mathrm{s}, \mathrm{C}_{\mathrm{q}} \mathrm{N}$ ), $135.0\left(\mathrm{~s}, \mathrm{C}_{4-\mathrm{Py}}\right), 129.8,129.5,128.2,124.6,123.0$, and 122.6 (all s, $\mathrm{CH}_{\mathrm{Ph}-\mathrm{IPr}}$ ), 124.4 and 123.7 (both s, $=\mathrm{CHN}$ ), $122.1\left(\mathrm{~s}, \mathrm{C}_{3-}\right.$ $\left.{ }_{P y}\right), 120.9\left(\mathrm{~s}, \mathrm{C}_{5-\mathrm{Py}}\right), 44.5$ and 36.9 (both d, $J_{\mathrm{C}-\mathrm{Rh}}=17.3$, $\mathrm{CH}_{2}=\mathrm{CH}_{2}$ ), $31.8\left(\mathrm{~s}, \mathrm{CH}_{2-\mathrm{Py}}\right.$ ), 29.4, 29.2, 28.8 and 28.6 (all s, $\underline{\mathrm{CHMe}}_{\mathrm{IPr}}$ ), 27.2, 26.6, 26.3, 26.1, 24.6, 23.3, 23.0 and 22.2 (all $\left.\mathrm{s}, \mathrm{CHMe}_{\mathrm{IPr}}\right), 13.6$ (s, $\left.\mathrm{CH}_{3-\mathrm{Py}}\right)$.

In-situ preparation of $\mathbf{R h C l H}(\mathrm{SPh})(\mathrm{IPr})(\mathrm{py})$ (11). A solution of 3 (23 mg, $0.032 \mathrm{mmol})$ in $\mathrm{C}_{6} \mathrm{D}_{6}(0.5 \mathrm{~mL}, \mathrm{NMR}$-tube $)$ at $20{ }^{\circ} \mathrm{C}$ was treated with thiophenol $(2.3 \mu \mathrm{L}, 0.034 \mathrm{mmol}) .{ }^{1} \mathrm{H}$ NMR $\left(500 \mathrm{MHz}, \mathrm{C}_{6} \mathrm{D}_{6}, 293 \mathrm{~K}\right): \delta 8.96\left(\mathrm{~d}, J_{\mathrm{H}-\mathrm{H}}=5.0,2 \mathrm{H}, \mathrm{H}_{2}\right.$ Py) $7.42-6.88\left(\mathrm{~m}, 11 \mathrm{H}, \mathrm{H}_{\mathrm{Ph}}\right), 6.85(\mathrm{~s}, 2 \mathrm{H},=\mathrm{CHN}), 6.26\left(\mathrm{~d}, J_{\mathrm{H}-\mathrm{H}}\right.$ $\left.=7.6,1 \mathrm{H}, \mathrm{H}_{4-\mathrm{Py}}\right), 5.95\left(\mathrm{dd}, J_{\mathrm{H}-\mathrm{H}}=7.6-5.0,2 \mathrm{H}, \mathrm{H}_{3-\mathrm{Py}}\right), 3.76$ and 3.66 (both sept, $J_{\mathrm{H}-\mathrm{H}}=6.3,4 \mathrm{H}, \mathrm{CHMe} \underline{\mathrm{HPr}}_{\mathrm{Pr}}$ ), 1.96, 1.53, 1.26 and $1.10\left(\right.$ all d, $\left.J_{\mathrm{H}-\mathrm{H}}=6.3,24 \mathrm{H}, \mathrm{CHM} \underline{\mathrm{MPr}}_{\mathrm{IPr}}\right),-26.55\left(\mathrm{~d}, J_{\mathrm{Rh}-\mathrm{H}}=48.5\right.$, $1 \mathrm{H}, \mathrm{Rh}-\mathrm{H})$.

In-situ preparation of $\mathrm{RhClH}(\mathrm{SPh})(\mathrm{IPr})(\mathrm{py})_{2}$ (11-py). A solution of $1(22 \mathrm{mg}, 0.017 \mathrm{mmol})$ in toluene- $d_{8}(0.5 \mathrm{~mL}$, NMR-tube) at $-30{ }^{\circ} \mathrm{C}$ was treated with pyridine $(8 \mu \mathrm{L}, 0.102$ mmol) and thiophenol $(2.3 \mu \mathrm{L}, 0.034 \mathrm{mmol})$. The ${ }^{1} \mathrm{H}$ NMR was immediately recorded at low temperature. A mixture of $\mathbf{1 1}$ and 11-py were observed in 1:2.5 ratio (at $293 \mathrm{~K}$ ). Data for 11-py: ${ }^{1} \mathrm{H}$ NMR $\left(500 \mathrm{MHz}\right.$, tol- $\left.d_{8}, 243 \mathrm{~K}\right): \delta 9.58$ and 9.31 (both br, 2H, $\mathrm{H}_{\mathrm{o}-\mathrm{Py}-\mathrm{A}}$ ), 9.06 (br, 2H, $\mathrm{H}_{\mathrm{o}-\mathrm{Py}-\mathrm{B}}$ ), 7.40-6.40 (br, $11 \mathrm{H}, \mathrm{H}_{\mathrm{Ph}}$ and $\left.=\mathrm{CHN}\right), 6.62\left(\mathrm{br}, 1 \mathrm{H}, \mathrm{H}_{\mathrm{p}-\mathrm{Py}-\mathrm{A}}\right), 6.24\left(\mathrm{br}, 1 \mathrm{H}, \mathrm{H}_{\mathrm{p}-}\right.$ Py-B), 6.51 and 6.07 (both br, 2H, $\mathrm{H}_{\mathrm{m}-\mathrm{Py}-\mathrm{A}}$ ), 6.06 (br, 2H, $\mathrm{H}_{\mathrm{m}-\mathrm{Py}-}$ в), 4.37, 4.02, 3.51 and 3.26 (all br, $4 \mathrm{H}, \underline{\mathrm{CHMe}}_{\mathrm{IPr}}$ ), 2.21, 1.67, $1.65,1.60,1.33,1.22,1.17$ and 1.04 (all br, 24H, CHMe $\underline{\mathrm{MPr}}_{\mathrm{IP}}$ ), $16.27\left(\mathrm{~d}, J_{\mathrm{Rh}-\mathrm{H}}=15.4,1 \mathrm{H}, \mathrm{Rh}-\mathrm{H}\right)$.

In-situ preparation of $\mathrm{RhClH}\left(\mathrm{SCH}_{2} \mathrm{Ph}\right)(\mathrm{IPr})(\mathrm{py})_{2}(12-\mathrm{py})$. A solution of $1(22 \mathrm{mg}, 0.017 \mathrm{mmol})$ in toluene- $d_{8}(0.5 \mathrm{~mL}$, NMR-tube) at $-30{ }^{\circ} \mathrm{C}$ was treated with pyridine $(8 \mu \mathrm{L}, 0.102$ mmol) and benzylthiol $(3.6 \mu \mathrm{L}, 0.034 \mathrm{mmol})$. The ${ }^{1} \mathrm{H}$ NMR was immediately recorded at low temperature. ${ }^{1} \mathrm{H}$ NMR (500 $\mathrm{MHz}$, tol- $d_{8}, 223 \mathrm{~K}$ ): $\delta 9.49$ and 9.20 (both $\mathrm{d}, J_{\mathrm{H}-\mathrm{H}}=4.9,2 \mathrm{H}$, $\left.\mathrm{H}_{\mathrm{o}-\mathrm{Py}-\mathrm{A}}\right), 9.44\left(\mathrm{~d}, J_{\mathrm{H}-\mathrm{H}}=5.2,2 \mathrm{H}, \mathrm{H}_{\mathrm{o}-\mathrm{Py}-\mathrm{B}}\right), 7.40-6.90(\mathrm{~m}, 11 \mathrm{H}$, $\mathrm{H}_{\mathrm{Ph}}$ ), 6.72 and 6.49 (both br, $2 \mathrm{H},=\mathrm{CHN}$ ), $6.61\left(\mathrm{br}, 1 \mathrm{H}, \mathrm{H}_{\mathrm{p}-\mathrm{Py}-}\right.$ A), 6.43 (br, 1H, $\mathrm{H}_{\mathrm{p}-\mathrm{Py}-\mathrm{B}}$ ), 6.42 and 5.96 (both br, 2H, $\mathrm{H}_{\mathrm{m}-\mathrm{Py}-\mathrm{A}}$ ), 6.24 (br, $2 \mathrm{H}, \mathrm{H}_{\mathrm{m}-\mathrm{Py}-\mathrm{B}}$ ), 4.56, 3.97, 3.55 and 2.85 (all sept, $J_{\mathrm{H}-\mathrm{H}}$ $=6.2,4 \mathrm{H}, \mathrm{CHMe}_{\mathrm{IPr}}$ ), 2.45 and 2.20 (both d, $J_{\mathrm{H}-\mathrm{H}}=11.7,2 \mathrm{H}$, $\mathrm{CH}_{2} \mathrm{~S}$ ), 2.06, 1.87, 1.71, 1.34, 1.32, 1.22, 1.16 and 0.93 (all d, $\left.J_{\mathrm{H}-\mathrm{H}}=6.2,24 \mathrm{H}, \mathrm{CHMe}_{\mathrm{IPr}}\right),-17.10\left(\mathrm{~d}, J_{\mathrm{Rh}-\mathrm{H}}=15.2,1 \mathrm{H}, \mathrm{Rh}-\mathrm{H}\right)$.

In-situ preparation of $\mathbf{R h C l H}\left(\mathrm{SCH}_{2} \mathbf{P h}\right)(\mathrm{IPr})(2-\mathrm{Etpy})$ (13). A solution $10(19 \mathrm{mg}, 0.026 \mathrm{mmol})$ in toluene- $d_{8}(0.5$ $\mathrm{mL}, \mathrm{NMR}$-tube) at $-50{ }^{\circ} \mathrm{C}$ was treated with benzylthiol $(3 \mu \mathrm{L}$, $0.028 \mathrm{mmol})$. The ${ }^{1} \mathrm{H}$ NMR was immediately recorded at low temperature. ${ }^{1} \mathrm{H}$ NMR $\left(500 \mathrm{MHz}\right.$, tol- $\left.d_{8}, 223 \mathrm{~K}\right): \delta 7.68\left(\mathrm{~d}, J_{\mathrm{H}-}\right.$ $\left.\mathrm{H}=5.0,1 \mathrm{H}, \mathrm{H}_{6-\mathrm{Py}}\right), 7.40-7.00\left(\mathrm{~m}, 11 \mathrm{H}, \mathrm{H}_{\mathrm{Ph}}\right), 6.60\left(\mathrm{dd}, J_{\mathrm{H}-\mathrm{H}}=\right.$ $\left.8.7, J_{\mathrm{H}-\mathrm{H}}=7.6,1 \mathrm{H}, \mathrm{H}_{4-\mathrm{Py}}\right), 6.59$ and 6.56 (both br, $2 \mathrm{H},=\mathrm{CHN}$ ), $6.20\left(\mathrm{~d}, J_{\mathrm{H}-\mathrm{H}}=7.6,1 \mathrm{H}, \mathrm{H}_{3-\mathrm{Py}}\right), 6.02\left(\mathrm{dd}, J_{\mathrm{H}-\mathrm{H}}=8.7, J_{\mathrm{H}-\mathrm{H}}=5.0\right.$, $1 \mathrm{H}, \mathrm{H}_{5-\mathrm{Py}}$ ), 3.82, 3.80, 3.50 and 3.31 (all sept, $J_{\mathrm{H}-\mathrm{H}}=6.2,4 \mathrm{H}$, $\mathrm{CHMe}_{\mathrm{IPr}}$ ), 2.48-2.42 (m, 2H, $\mathrm{CH}_{2-\mathrm{Py}}$ ), 2.78 and 2.49 (both d, $\left.J_{\mathrm{H}-\mathrm{H}}=12.5,2 \mathrm{H}, \mathrm{CH}_{2} \mathrm{~S}\right), 1.78,1.73,1.69,1.58,1.22,1.17,1.15$ and 1.06 (all d, $\left.J_{\mathrm{H}-\mathrm{H}}=6.2,24 \mathrm{H}, \mathrm{CHMe} \underline{\mathrm{IPr}}_{\mathrm{IP}}\right), 0.89\left(\mathrm{dd}, J_{\mathrm{H}-\mathrm{H}}=\right.$ 7.5-7.3, 3H, $\mathrm{CH}_{3-\mathrm{Py}}$ ), -26.93 (d, $\left.J_{\mathrm{Rh}-\mathrm{H}}=47.0,1 \mathrm{H}, \mathrm{Rh}-\mathrm{H}\right)$.

Preparation of S-(phenylvinyl)-N-Boc-L-cysteinemethylester. A Schelnk tube containing $1 \mathrm{ml}$ of toluene was charged with $11.1 \mathrm{mg}(0.01 \mathrm{mmol})$ of catalyst $2,16 \mu \mathrm{L}$ of pyridine (15.6 mg, $0.2 \mathrm{mmol}), 200 \mu \mathrm{L}(229 \mathrm{mg}, 1 \mathrm{mmol})$ of $\mathrm{N}$ (tert-butoxycarbonyl)-L-cysteine methyl ester and $110 \mu \mathrm{L}(102$ $\mathrm{mg}, 1 \mathrm{mmol}$ ) of phenylacetylene were added. The yellow 
solution was stirred for 30 minutes at r.t. and then filtered through silica gel, in order to remove the catalyst. Finally the solution was concentrated under vacuum and analyzed by NMR. The conversion was complete and a ratio of 90/10 of branched/linear hydrothiolation product was obtained. S-(1phenylvinyl)-N-Boc-L-cysteine-methylester: ${ }^{1} \mathrm{H}$ NMR $(500$ $\left.\mathrm{MHz}, \mathrm{C}_{6} \mathrm{D}_{6}, 298 \mathrm{~K}\right): \delta 7.58\left(\mathrm{~d}, J_{\mathrm{H}-\mathrm{H}}=6.8,2 \mathrm{H}, \mathrm{H}_{\mathrm{o}-\mathrm{Ph}}\right), 7.23-$ $7.18\left(\mathrm{~m}, 3 \mathrm{H}, \mathrm{H}_{\mathrm{m}+\mathrm{p}-\mathrm{Ph}}\right), 5.70\left(\mathrm{~d}, J_{\mathrm{H}-\mathrm{H}}=8.4,1 \mathrm{H}, \mathrm{NH}\right), 5.44$ and 5.38 (both s, $\left.2 \mathrm{H},=\mathrm{CH}_{2}\right), 4.79\left(\mathrm{dt}, J_{\mathrm{H}-\mathrm{H}}=8.4 J_{\mathrm{H}-\mathrm{H}}=4.9,1 \mathrm{H}\right.$, $\mathrm{NCH}), 3.34\left(\mathrm{~s}, 3 \mathrm{H}, \mathrm{OCH}_{3}\right), 3.14$ and $2.97\left(\mathrm{dd}, J_{\mathrm{H}-\mathrm{H}}=13.7, J_{\mathrm{H}-}\right.$ $\left.{ }_{\mathrm{H}}=4.9,2 \mathrm{H}, \mathrm{SCH}_{2}\right), 1.49\left(\mathrm{~s}, 9 \mathrm{H}, \mathrm{CH}_{3-\mathrm{tBu}}\right) .{ }^{13} \mathrm{C}\left\{{ }^{1} \mathrm{H}\right\}$ APT NMR plus HSQC and HMBC (125.6 MHz, $\left.\mathrm{C}_{6} \mathrm{D}_{6}, 298 \mathrm{~K}\right): \delta 171.0$ (s, C- $\underline{C}=\mathrm{O}), 155.1(\mathrm{~s}, \mathrm{~N}-\underline{\mathrm{C}}=\mathrm{O}), 144.1\left(\mathrm{~s}, \underline{\mathrm{C}}=\mathrm{CH}_{2}\right), 139.3\left(\mathrm{~s}, \mathrm{C}_{\mathrm{q}-}\right.$ $\mathrm{Ph}), 128.5\left(\mathrm{~s}, \mathrm{C}_{\mathrm{p}-\mathrm{Ph}}\right), 128.4\left(\mathrm{~s}, \mathrm{C}_{\mathrm{m}-\mathrm{Ph}}\right), 127.5\left(\mathrm{~s}, \mathrm{C}_{\mathrm{o}-\mathrm{Ph}}\right), 113.3(\mathrm{~s}$, $\left.=\underline{\mathrm{CH}}_{2}\right), 79.4\left(\mathrm{~s}, \mathrm{C}_{\mathrm{q}-\mathrm{tBu}}\right), 53.2(\mathrm{~s}, \mathrm{~N}-\underline{\mathrm{CH}}), 51.7\left(\mathrm{~s}, \mathrm{O}-\underline{\mathrm{CH}}_{3}\right), 34.3$ (s, S- $\left.\underline{\mathrm{CH}}_{2}\right), 28.1$ (s, $\left.\underline{\mathrm{CH}}_{3-\mathrm{tBu}}\right)$. S-(2-phenylvinyl)-N-Boc-Lcysteine-methylester. ${ }^{1} \mathrm{H}$ NMR $\left(500 \mathrm{MHz}, \mathrm{C}_{6} \mathrm{D}_{6}, 298 \mathrm{~K}\right): \delta$ $7.61\left(\mathrm{~d}, J_{\mathrm{H}-\mathrm{H}}=6.9,2 \mathrm{H}, \mathrm{H}_{\mathrm{o}-\mathrm{Ph}}\right), 7.25-7.15\left(\mathrm{~m}, 3 \mathrm{H}, \mathrm{H}_{\mathrm{m}+\mathrm{p}-\mathrm{Ph}}\right), 6.65$ $\left(\mathrm{d}, J_{\mathrm{H}-\mathrm{H}}=15.6,1 \mathrm{H}, \mathrm{S}-\mathrm{CH}=\right), 6.59\left(\mathrm{~d}, J_{\mathrm{H}-\mathrm{H}}=15.6,1 \mathrm{H},=\underline{\mathrm{HC}}-\right.$ $\mathrm{Ph}), 5.73\left(\mathrm{~d}, J_{\mathrm{H}-\mathrm{H}}=8.0,1 \mathrm{H}, \mathrm{NH}\right), 4.81\left(\mathrm{dt}, J_{\mathrm{H}-\mathrm{H}}=8.0-4.8,1 \mathrm{H}\right.$, $\mathrm{N}-\mathrm{CH}), 3.38\left(\mathrm{~s}, 3 \mathrm{H}, \mathrm{O}-\mathrm{CH}_{3}\right), 3.23$ and $3.11\left(\mathrm{dd}, J_{\mathrm{H}-\mathrm{H}}=14.1-\right.$ $\left.4.8,2 \mathrm{H}, \mathrm{S}-\mathrm{CH}_{2}\right), 1.47$ (s, 9H, $\left.\mathrm{CH}_{3-\mathrm{tBu}}\right) .{ }^{13} \mathrm{C}\left\{{ }^{1} \mathrm{H}\right\}$ APT NMR plus HSQC and HMBC (125.6 MHz, $\left.\mathrm{C}_{6} \mathrm{D}_{6}, 298 \mathrm{~K}\right): \delta 170.8$ (s, C- $\underline{C}=\mathrm{O}), 155.0(\mathrm{~s}, \mathrm{~N}-\underline{\mathrm{C}}=\mathrm{O}), 136.9\left(\mathrm{~s}, \mathrm{C}_{\mathrm{q}-\mathrm{Ph}}\right), 129.1(\mathrm{Ph}-$ $\underline{\mathrm{CH}}=\mathrm{CH}), 128.6\left(\mathrm{~s}, \mathrm{C}_{\mathrm{m}-\mathrm{Ph}}\right), 127.1\left(\mathrm{~s}, \mathrm{C}_{\mathrm{p}-\mathrm{Ph}}\right), 125.8\left(\mathrm{~s}, \mathrm{C}_{\mathrm{o}-\mathrm{Ph}}\right)$, $121.6(\mathrm{~s}, \mathrm{C}=\underline{\mathrm{C}} \mathrm{H}-\mathrm{S}), 79.5\left(\mathrm{~s}, \mathrm{C}_{\mathrm{q}-\mathrm{tBu}}\right), 53.8(\mathrm{~s}, \mathrm{~N}-\underline{\mathrm{C}} \mathrm{H}), 51.9$ (s, O$\left.\underline{\mathrm{CH}}_{3}\right), 35.4\left(\mathrm{~s}, \mathrm{~S}-\underline{\mathrm{C}} \mathrm{H}_{2}\right), 28.0\left(\mathrm{~s}, \underline{\mathrm{CH}}_{3-\mathrm{tBu}}\right)$.

\section{Preparation of Phenyl(1-(4- (trifluoromethyl)phenyl)vinyl)sulfane.The product was} prepared as descrive for S-(phenylvinyl)-N-Boc-L-cysteinemethylester starting for 1-ethynyl-4-(trifluoromethyl)benzene (158 $\mu \mathrm{L}, 1 \mathrm{mmol})$. The reaction time was $4 \mathrm{~h}$, the conversion was complete and a ratio of $97 / 3$ of branched/linear hydrothiolation product was obtained. ${ }^{1} \mathrm{H}$ NMR $\left(500 \mathrm{MHz}, \mathrm{C}_{6} \mathrm{D}_{6}\right.$, $298 \mathrm{~K}): \delta 7.53\left(\mathrm{~d}, J_{\mathrm{H}-\mathrm{H}}=8.1,2 \mathrm{H}, \mathrm{H}_{2-\mathrm{Ph}-\mathrm{CF} 3}\right), 7.38\left(\mathrm{~m}, 2 \mathrm{H}, \mathrm{H}_{\mathrm{o}-\mathrm{Ph}-}\right.$ $\mathrm{s}), 7.33\left(\mathrm{~d}, J_{\mathrm{H}-\mathrm{H}}=8.1,2 \mathrm{H}, \mathrm{H}_{3-\mathrm{Ph}-\mathrm{CF} 3}\right), 7.05\left(\mathrm{~m}, 2 \mathrm{H}, \mathrm{H}_{\mathrm{m}-\mathrm{Ph}-\mathrm{S}}\right)$, $6.99\left(\mathrm{~m}, 1 \mathrm{H}, \mathrm{H}_{\mathrm{p}-\mathrm{Ph}-\mathrm{S}}\right.$ ), 5.51 and 5.39 (both s, $\left.\mathrm{C}=\mathrm{C}_{2}\right) .{ }^{13} \mathrm{C}\left\{{ }^{1} \mathrm{H}\right\}$ APT NMR plus HSQC and HMBC (125.6 MHz, $\mathrm{C}_{6} \mathrm{D}_{6}, 298$ $\mathrm{K}): \delta 143.6\left(\mathrm{~s}, \underline{\mathrm{C}}=\mathrm{CH}_{2}\right), 142.3\left(\mathrm{~s}, \mathrm{C}_{1-\mathrm{Ph}-\mathrm{CF} 3}\right), 133.3$ (s, $\left.\mathrm{C}_{\mathrm{q}-\mathrm{Ph}-\mathrm{S}}\right)$, $132.0\left(\mathrm{~s}, \mathrm{C}_{\mathrm{o}-\mathrm{Ph}-\mathrm{S}}\right), 130.2\left(\mathrm{q}, J_{\mathrm{C}-\mathrm{F}}=32.4, \mathrm{C}_{4-\mathrm{Ph}-\mathrm{CF} 3}\right), 129.2\left(\mathrm{~s}, \mathrm{C}_{\mathrm{m}-}\right.$ Ph-S $), 127.6\left(\mathrm{~s}, \mathrm{C}_{2-\mathrm{Ph}-\mathrm{CF} 3}\right), 127.5\left(\mathrm{~s}, \mathrm{C}_{\mathrm{p}-\mathrm{Ph}-\mathrm{S}}\right), 125.3\left(\mathrm{q}, J_{\mathrm{C}-\mathrm{F}}=3.8\right.$, $\left.\mathrm{C}_{3 \text {-Ph-CF3 }}\right), 124.5\left(\mathrm{q}, J_{\mathrm{C}-\mathrm{F}}=272.6, \underline{\mathrm{CF}}_{3}\right), 117.61\left(\mathrm{~s}, \mathrm{C}=\mathrm{CH}_{2}\right) .{ }^{19} \mathrm{~F}$ NMR (470 MHz, $\left.\mathrm{C}_{6} \mathrm{D}_{6}, 298 \mathrm{~K}\right): \delta-62.39\left(\mathrm{~s}, \mathrm{CF}_{3}\right)$.

Preparation of 1,6-bis((1-phenylvinyl)thio)hexane. The product was prepared as described for S-(phenylvinyl)-N-BocL-cysteine-methylester starting for 1,6-hexanedithiol (40 $\mu \mathrm{L}$, $0.5 \mathrm{mmol})$ with a molar ratio 1,6hexanedithiol:phenylacetilene $=1: 2$. The reaction time was 0,7 $\mathrm{h}$, the conversion was complete and a ratio of 88/12 of branched-branched/branched-linear hydrothiolation product was obtained. 1,6-bis((1-phenylvinyl)thio)hexane: ${ }^{1} \mathrm{H}$ NMR $\left(300 \mathrm{MHz}, \mathrm{C}_{6} \mathrm{D}_{6}, 298 \mathrm{~K}\right): \delta 7.72\left(\mathrm{dd}, J_{\mathrm{H}-\mathrm{H}}=8.1, J_{\mathrm{H}-\mathrm{H}}=1.2\right.$, $4 \mathrm{H}, \mathrm{H}_{\mathrm{o}-\mathrm{Ph}}$ ), 7.3-7.1 (br, 6H, $\mathrm{H}_{\mathrm{m}+\mathrm{p}-\mathrm{Ph}}$ ), 5.51 and 5.24 (both s, $4 \mathrm{H}$, $\left.\mathrm{C}=\mathrm{CH}_{2}\right), 2.54,1,50$ and $1,17\left(\mathrm{br}, 12 \mathrm{H}, \mathrm{CH}_{2 \text {-alkylic }}\right) .{ }^{13} \mathrm{C}\left\{{ }^{1} \mathrm{H}\right\}$ APT NMR plus HSQC and HMBC (75.4 MHz, $\left.\mathrm{C}_{6} \mathrm{D}_{6}, 298 \mathrm{~K}\right)$ : $\delta 145.8\left(\mathrm{~s} \underline{\mathrm{C}}=\mathrm{CH}_{2}\right), 140.1\left(\mathrm{~s}, \mathrm{C}_{\mathrm{q}-\mathrm{Ph}}\right), 128.4\left(\mathrm{~s}, \mathrm{C}_{\mathrm{m}-\mathrm{Ph}}\right), 128.3(\mathrm{~s}$, $\left.\mathrm{C}_{\mathrm{p}-\mathrm{Ph}}\right), 127.3\left(\mathrm{~s}, \mathrm{C}_{\mathrm{o}-\mathrm{Ph}}\right), 110.3\left(\mathrm{~s}, \mathrm{C}=\underline{\mathrm{CH}}_{2}\right), 31.9,28.4$ and 28.3 (all s, $\underline{\mathrm{CH}}_{2-\text { Alkylic). }}$.

Standard catalytic conditions. In a NMR tube 0.01 equivalent of catalyst were dissolved in $0.5 \mathrm{~mL}$ of $\mathrm{C}_{6} \mathrm{D}_{6}$ and then 0.5 mmol of thiol and $0.5 \mathrm{mmol}$ of alkyne were added. The alkyne conversion to vinyl sulfide and the conversion was quantified by integration of the ${ }^{1} \mathrm{H}-\mathrm{NMR}$ spectrum. Reaction product formation was also monitored at periodic time intervals by using GC-MS analyses.

Molecular Structure Determination for complexes 2 and 3. Single crystals for the X-ray diffraction study of $\mathbf{2}$ and $\mathbf{3}$ were grown by slow diffusion of $n$-hexane into a saturated solution of the complexes in toluene. Intensity data for both complexes were collected at low temperature $(100(2) \mathrm{K})$ on a Bruker SMART CCD area detector diffractometer equipped with graphite monochromated Mo-K $\alpha$ radiation $(\lambda=0.71073$ $\AA)$ using narrow frames $\left(0.3^{\circ}\right.$ in $\left.\omega\right)$. Data were corrected for Lorentz and polarization effects, and a semiempirical absorption correction was applied using SADABS program. ${ }^{49}$ The structures were solved by Patterson method and completed by successive difference Fourier syntheses. Refinements were carried out by full-matrix least-squares on $F^{2}$ with SHELXL$97,{ }^{50}$ including isotropic and subsequent anisotropic displacement parameters for all non-hydrogen atoms. Hydrogen atoms for the ethylene molecules in $\mathbf{2}$ were obtained from difference Fourier maps and refined as free isotropic atoms; the rest of hydrogens were included in calculated positions and refined as riding atoms. In the case of $\mathbf{3}$, two regions of disorder were observed and modeled with two moieties with complementary occupancy factors. Only two residual peaks above $1.00 \mathrm{e}^{-} / \AA^{3}$ were observed in $\mathbf{3}$, but were located in close proximity of the rhodium atoms.

Crystal data for 2: $\mathrm{C}_{58} \mathrm{H}_{80} \mathrm{Cl}_{2} \mathrm{~N}_{4} \mathrm{Rh}_{2}, M=1109.98$, triclinic, space group $P \overline{1}$, orange crystal $0.191 \times 0.186 \times 0.154 \mathrm{~mm}, a$ $=10.2222(4), b=12.2208(5), c=13.5228(5) \AA, \alpha=$ 101.2870(5), $\beta=110.5192(5), \gamma=111.5633(4)^{\circ}, \quad V=$ $1365.44(9) \AA^{3}, Z=1, \mu(\operatorname{MoK} \alpha)=0.742 \mathrm{~mm}^{-1}, D_{\text {calc }}=1.35 \mathrm{~g}$ $\mathrm{cm}^{-3}$, min \& max. trans. factors 0.804 and 0.907 .16152 reflections measured $\left(1.73 \leq \theta \leq 30.52^{\circ}, \operatorname{sen} \theta / \lambda \leq 0.715 \AA^{-1}\right), 7570$ independent reflections $\left(R_{\text {int }}=0.0161\right)$; number of data/restrains/parameters $7570 / 0 / 322$. The final $R_{1}$ and $w R\left(F^{2}\right)$ values were 0.0216 and 0.0553 for $I>2 \sigma(I)$, and 0.0227 and 0.0560 for all data, respectively; $S=1.035$ for all data.

Crystal data for 3: $\mathrm{C}_{40} \mathrm{H}_{55} \mathrm{ClN}_{3} \mathrm{Rh}, M=716.26$, triclinic, space group $P \overline{1}$, yellow crystal $0.213 \times 0.161 \times 0.057 \mathrm{~mm}, a$ $=10.374(3), b=10.874(3), c=17.559(4) \AA, \alpha=85.301(3), \beta$ $=75.467(3), \gamma=72.538(3)^{\circ}, V=1829.1(8) \AA^{3}, Z=2$, $\mu(\mathrm{MoK} \alpha)=0.571 \mathrm{~mm}^{-1}, D_{\text {calc }}=1.301 \mathrm{~g} \mathrm{~cm}^{-3}$, min \& max. absorp. correc. factors 0.813 and 1.139. 18989 reflections measured $\left(1.96 \leq \theta \leq 26.37^{\circ}\right.$, $\left.\operatorname{sen} \theta / \lambda \leq 0.625 \AA^{-1}\right), 7439$ independent reflections $\left(R_{\text {int }}=0.0667\right)$; number of data/restrains/parameters $7439 / 6 / 455$. The final $R_{l}$ and $w R\left(F^{2}\right)$ values were 0.0570 and 0.1263 for $I>2 \sigma(I)$, and 0.0893 and 0.1372 for all data, respectively. The goodness of fit on $F^{2}$ was 1.006.

Computational Details. All the calculations have been performed with the Gaussian09 package $^{51}$ at the B3LYP level. ${ }^{52}$ The rhodium atom was were represented by the relativistic effective core potential (RECP) from the Stuttgart group and the associated basis set. ${ }^{53}$ The remaining atoms $(\mathrm{C}, \mathrm{H}, \mathrm{N}, \mathrm{O}$, $\mathrm{Cl}, \mathrm{S}$ ) were represented by a $6-31 \mathrm{G}(\mathrm{d})$ basis set. Full optimizations of geometry without any constraint were performed, followed by analytical computation of the Hessian matrix to 
confirm the nature of the stationary points as minima or transition structure on the potential energy surface.

Determination of rotational barriers. Full line-shape analysis of the dynamic ${ }^{1} \mathrm{H}$ NMR spectra of 2, 3, 4 and 6 were carried out using the program gNMR (Cherwell Scientific Publishing Limited). The transverse relaxation time, $T_{2}$, was estimated at the lowest temperature. Activation parameters $\Delta \mathrm{H}^{\neq}$and $\Delta \mathrm{S}^{\neq}$were obtained by linear least-squares fit of the Eyring plot. Errors were computed by published methods. ${ }^{48}$

\section{ASSOCIATED CONTENT}

Crystalographic data and processing parameters for compounds $\mathbf{2}$ and $\mathbf{3}$, determination of thermodynamic parameters of the equilibrium between $\mathbf{6}$ and 2, cartesian coordinate for theoretical calculated compounds, and complete Reference 51. This material is available free of charge via the Internet at http://pubs.acs.org.

\section{AUTHOR INFORMATION}

\section{Corresponding Author}

$\underline{\text { rcastar@unizar.es }}$

\section{ACKNOWLEDGMENT}

Financial support from the Ministerio de Ciencia e Innovación (MICINN/FEDER) of Spain (Project CTQ2010-15221), the Diputación General de Aragón (E07), the ARAID Foundation under the program "Jóvenes Investigadores", and CONSOLIDER INGENIO-2010, Projects MULTICAT (CSD2009-00050) and Factoría de Cristalización (CSD2006-0015) are gratefully acknowledged. R.C. thanks the CSIC and the European Social Fund for his Research Contract in the framework of the "Ramón $y$ Cajal" Program.

\section{REFERENCES}

(1) (a) Meng, D.; Chen, W.; Zhao, W. J. Nat. Prod. 2004, 70, 824. (b) Sader, H. S.; Johnson, D. M.; Jones, R. N. Antimicrob. Agents Chemother. 2004, 48, 53. (c) Szilágyi, Á; Fenyvesi, F.; Mayercsik, O.; Pelyvás, I. S.; Bácskay, I.; Fehér, P.; Váradi, J.; Vecsernyés, M.; Herczegh, P. J. Med. Chem. 2006, 49, 5626.

(2) (a) Dvorak, C. A.; Schmitz, W. D.; Poon, D. J.; Pryde, D. C.; Lawson, J. P.; Amos, R. A.; Meyers, A. I. Angew. Chem. Int. Ed. 2000, 39, 1664. (b) Ceruti, M; Balliano, G.; Rocco, F.; Milla, P.; Arpicco, S.; Cattel, L.; Viola, F. Lipids 2001, 36, 629. (c) Johannesson, P.; Lindeberg, G.; Johansson, A.; Nikiforovich, G. V.; Gogoll, A.; Synnergren, B., LeGrèves, M., Nyberg, F.; Karlén, A.; Hallberg, A. J. Med. Chem. 2002, 45, 1767.

(3) Schaumann, E. Top. Curr. Chem. 2007, 274, 1. 5075 .

(4) Trost, B. M.; Lavoie, A. C. J. Am. Chem. Soc. 1983, 105,

(5) (a) Chou, S.-S. P; Wey, S.-J. J. Org. Chem. 1990, 55, 1270 (b) Surasani, S. R.; Peddinti, R. K. Tetrahedron Lett. 2011, 52, 1270

(6) (a) Boaz, N. W.; Fox, K. M. J. Org. Chem. 1993, 58, 3042. (b) Majumdar, K. C.; Kundu, U. K.; Ghosh, S. K. Org. Lett. 2002, 4, 2629. (c) Fernandez de la Pradilla, R.; Tortosa, M.; Viso, A. Top. Curr. Chem. 2007, 275, 103. (d) Liu, Z.; Mehta, S. J.; Lee, K.-S.; Grossman, B.; Qu, H; Gu, X.; Nichol, G. S.; Hruby, L. J. J. Org. Chem. 2012, 77, 1289.

(7) Mizuno, H.; Domon, K., Masuya, K.; Tanino, K., Kuwajima, I. J. Org. Chem. 1999, 64, 2648.

(8) (a) Liu, Z.; Rainier, J. D. Org. Lett. 2005, 7, 131. (b) Macnaughtan, M. L.; Gary, J. B.; Gerlach, D. L.; Johnson, M. J. A.; Kampf, J. W. Organometallics 2009, 28, 2880.

(9) (a) Sabarre, A.; Love, J. Org. Lett. 2008, 10, 3941. (b) Braun, M.-G.; Zard, S. Z. Org. Lett. 2011, 13, 776. (c) Jin, W.;
Du,W.; Yang, Q.; Yu, H.; Chen, J.; Yu, Z. Org. Lett. 2011, 13, 4272. (d) Zhu, Y.; Xie, M.; Dong, S.; Zhao, X.; Lin, L.; Liu, X.; Feng, X. Chem Eur. J. 2011, 17, 8202. (e) Cui, Y.; Floreancing, P. E. Org. Lett. 2012, 14, 1720.

(10) McDonald, J. V.; Corbin, J. L.; Newton, W. E. Inorg. Chem. 1976, 15, 2056.

(11) (a) Kuniyasu, H.; Ogawa, A.; Sato, K.-I.; Ryu, I.; Kambe, N.; Sonoda, N. J. Am. Chem. Soc 1992, 114, 5902. (b) Bäckvall, J.E.; J. Org. Chem. 1994, 59, 5850. (c) Ogawa, A.; Ikeda, T.; Kimura, K.; Hirao, J. J. Am. Chem. Soc. 1999, 121, 5108. (d) Kondoh, A.; Yorimitsu, H.; Oshima, K. Org. Lett. 2007, 9, 1383. (e) Ananikov, V. P.; Orlov, N. V.; Beletskaya, I. P.; Khrustalev, V. N.; Antipin, M. Y.; Timofeeva, T. V. J. Am. Chem. Soc. 2007, 129, 7252. (f) Mitamura, T.; Daitou, M.; Nomoto, A.; Ogawa, A. Bull. Chem. Soc. Jpn. 2011, $84,413$.

(12) (a) Ogawa, A.; Kawakami, J.-I.; Mihara, M.; Ikeda, T.; Sonoda, N.; Irao, T. J. Am. Chem. Soc. 1997, 119, 12380. (b) Ananikov, V. P.; Beletskaya, I. P. Pure Appl. Chem. 2007, 79, 1041.

(13) (a) Han, L.-B.; Zhang, C.; Yazawa, H.; Shimada, S. J. Am. Chem. Soc. 2004, 126, 5080. (b) Ananikov, V. P.; Orlov, L. V.; Beletskaya, I. P. Organometallics, 2006, 25, 1970. (c) Malyshev, D. A.; Scott, N. M.; Marion, N.; Stevens E. D.; Ananikov, V. P.; Beletskaya, I. P.; Nolan, S. P. Organometallics, 2006, 25, 4462. (d) Ananikov, V. P.; Gayduck, K. A.; Orlov, N. V.; Beletskaya, I. P.; Khrustalev, V. N.; Antipin, M. Y. Chem. Eur. 2010, 16, 2063.

(14) Koelle, U.; Rietmann, C.; Tjoe, J.; Wagner, T.; Englert, U. Organometallics 2005, 14, 703.

(15) (a) Burling, S.; Field, L. D.; Messerle, B. A.; Vuong, K. Q.; Turner, P. Dalton Trans. 2003, 4181. (b) Cao, C.; Fraser, L. R.; Love, J. A. J. Am. Chem. Soc. 2005, 127, 17614. (c) Misumi, Y.; Seino, H.; Mizobe Y. J. Organomet. Chem. 2006, 691, 3157. (d) Fraser, L. R.; Bird, J.; Wu, Q.; Cao, C.; Patrick, B. O.; Love, J. A. Organometallics 2007, 26, 5602. (e) Shoai, S.; Bichler, P.; Kang, B.; Buckley, H.; Love, J. A. Organometallics 2007, 26, 5778. (f) Yang J.; Sabarre, A.; Fraser, L. R.; Patrick, B. O.; Love, J. A. J. Org. Chem. 2009, 74, 182. (g) Yang, Y.; Rioux, R. M. Chem. Commun. 2011, 47, 6557. (h) Liu, J.; Lam, J. W. Y.; Jin, C. K. W.; Ng, J. C. Y.; Shi, J.; Su, H.; Yeung, K. F.; Hong, Y.; Faisal, M.; Yu, Y.; Wong, K. S.; Tang, B. Z. Macromolecules 2011, 44, 68. (i) Zhao, H.; Peng, J.; Cai, M. Catal. Lett. 2012, 142, 138.

(16) Field, L. D.; Messerle, B. A.; Vuong, K. Q.; Turner, P. Dalton Trans. 2009, 3599.

(17) Delp, S. A.; Munro-leighton, C.; Goj, L. A.; Ramírez, M. A.; Gunnoe, T. B.; Petersen, J. L.; Boyle, P. D. Inorg. Chem. 2007, $46,2365$.

(18) Corma, A.; González-Arellano, C.; Iglesias, M.; Sánchez, F. Appl. Catal., A 2010, 375, 49.

(19) Higuchi, Y.; Atobe, S.; Tanaka, M.; Kamiya, I.; Yamamoto, T.; Nomoto, A.; Sonoda, M.; Ogawa, A. Organometallics 2011, $30,4539$.

(20) Yadav, J. S.; Reddy, B. V. S.; Raju, A.; Ravindar, K.; Baishya, G. Chem. Lett. 2007, 36, 1474. 1053.

(21) Weiss, C. J.; Marks, T. J. J. Am. Chem. Soc. 2010, 132,

(22) (a) Weiss, C. J.; Wobser, S. D.; Marks, T. J. J. Am. Chem. Soc. 2009, 131, 2062. (b) Weiss, C. J.; Wobser, S. D.; Marks, T. J. Organometallics 2010, 29, 6308.

(23) (a) Alonso, F.; Beletskaya, I. P.; Yus, M. Chem. Rev. 2004, 104, 379. (b) Beller, M.; Seayad, J.; Tillack, A.; Jiao, H. Angew. Chem. Int. Ed. 2004, 43, 3368. (c) Beletskaya, I. P.; Ananikov, V. P. Chem. Rev. 2011, 111, 1596.

(24) Examples where reductive elimination is proposed as the key step: (a) Ghosh, R.; Zhang, X.; Achord, P.; Emge, T. J.; KroghJespersen, K.; Goldman, A. S. J. Am. Chem. Soc. 2007, 129, 853. (b) Hyatt, I. F. D.; Anderson, H. K.; Morehead Jr., A. T.; Sargent, A. L. Organometallics 2008, 27, 135. (c) González-Rodríguez, C.; Pawley, R. J.; Chaplin, A. B.; Thompson, A. L.; Weller, A. S.; Willis, M. C. Angew. Chem. Int. Ed. 2011, 50, 5134.

(25) (a) Bassetti, M.; Casellato, P.; Gamasa, M. P.; Gimeno, J.; González-Bernardo, C.; Martín-Vaca, B. Organometallics 1997, 16, 5470. (b) Marchenko, A. V.; Gérard, H.; Eisenstein, O.; Caulton, K. 
G. New J. Chem. 2001, 25, 1244. (c) Li, X.; Vogel, T., Incarvito, D.; Crabtree, R. H. Organometallics 2005, 24, 62. (d) Di Tommaso, S.; Tognetti, V.; Sicilia, E.; Adamo, C.; Ruso, N. Inorg. Chem. 2010, 49, 9875.

(26) Some examples of 2,1 alkyne addition into a $\mathrm{M}-\mathrm{H}$ bond: (a) Weng, W.; Parking, S.; Ozerov, O. V. Organometallics 2006, 25, 5345. (b) She, L.; Li, X.; Sun, H.; Ding, J.; Frey, M.; Klein, H.-F. Organometallics 2007, 26, 566.

(27) (a) Ohtaka, A.; Kuniyasu, H.; Kinomoto, M.; Kurosawa, H. J. Am. Chem. Soc. 2002, 124, 14324. (b) Ogata, K.; Toyota, A. J. Organomet. Chem. 2007, 692, 4139.

(28) Sola, E.; García-Campubí A.; Andrés, J. L.; Martín, M.; Plou, P. J. Am. Chem. Soc. 2010, 132, 9111.

(29) (a) Herrmann, W. A. Angew. Chem. Int. Ed. 2002, 41, 1290. (b) Praetorius, J. M.; Crudden, C. M. Dalton Trans. 2008, 4079. (c) Arduengo III, A. J.; Iconaru, L. I. Dalton Trans. 2009, 6903. (d) Díez-González, S.; Marion, N.; Nolan, S. P. Chem. Rev. 2009, 109, 3612

(30) (a) Sanford, M. S.; Love, J. A.; Grubbs, R. H. J. Am. Chem. Soc. 2001, 123, 6543. (b) Lee, S.; Hartwig, J. F. J. Org. Chem 2001, 66, 3402. (c) Castarlenas, R.; Esteruelas, M. A.; Oñate, E Organometallics 2005, 24, 4343. (d) Herrmann, W. A.; Öfele, K. Schneider, S. K.; Herdtweck, E.; Hoffmann, S. D. Angew. Chem. Int. Ed. 2006, 45, 3859. (e) Würtz, S.; Glorius, F. Acc. Chem. Res. 2008 , 41, 1523. (f) Jiménez, M. V.; Pérez-Torrente, J. J.; Bartolomé, M. I.; Gierz, V.; Lahoz, F. J.; Oro, L. A. Organometallics 2008, 27, 224 (g) Zhu, Y.; Fan, Y.; Burgess, K. J. Am. Chem. Soc. 2010, 132, 6249. (h) Malik, H. A.; Surmunen, G. J.; Montgomery, J. J. Am. Chem. Soc. 2010, 132, 6304. (i) Ho, C.-Y.; He, L. Angew. Chem. Int. Ed. 2010, $49,9182$.

(31) (a) Scott, N. M.; Dorta, R.; Stevens, E. D.; Correa A.; Cavallo, L.; Nolan, S. P. J. Am. Chem. Soc. 2005, 127, 3516. (b) Yu, X. Y.; Patrick, B. O.; James, B. R. Organometallics 2006, 25, 4870. (c) Yu, X.-Y.; Sun, H.; Patrick, B. O.; James, B. R. Eur. J. Inorg. Chem. 2009, 1752. (d) Zenkina, O. V.; Keske, E. C.; Wang, R.; Crudden, C. M. Angew. Chem. Int. Ed. 2011, 50, 8100.

(32) (a) Di Giuseppe, A.; Castarlenas, R.; Pérez-Torrente, J. J.; Lahoz, F. J.; Polo, V.; Oro, L. A. Angew. Chem. Int. Ed. 2011, 50, 3938. (b) Palacios, L.; Miao, X.; Di Giuseppe, A.; Pascal, S.; Cunchillos, C.; Castarlenas, R.; Pérez-Torrente, J. J.; Lahoz, F. J.; Dixneuf, P. H.; Oro, L. A. Organometallics 2011, 30, 5208.

(33) Zenkina, O. V.; Keske, E. C.; Wang, R.; Crudden, C. M. Organometallics 2011, 30, 6423 .

(34) (a) Cramer, R. J. Am. Chem. Soc. 1964, 86, 217. (b) Wickeneiser, E. B.; Cullen, W. R. Inorg. Chem. 1990, 29, 4671. (c) Tejel, C.; Villoro, J. M.; Ciriano, M. A.; López, J. A.; Eguizábal, E. Lahoz, F. J., Bahkmutov, V. I.; Oro, L. A. Organometallics 1996, 15, 2967. (d) Friedman, L. A.; Meiere, S. H.; Brooks, B. J.; Harman, W. D. Organometallics 2001, 20, 1699. (e) Albietz, P. J.; Cleary, B. P.; Paw, W.; Eisenberg, R. Inorg. Chem. 2002, 41, 2095. (f) McBee, J. L.; Escalada, J.; Tilley, T. D. J. Am. Chem. Soc. 2009, 131, 12703.

(35) (a) Chianese, A. R.; Li, X.; Janzen, M. C.; Faller, J. W.; Crabtree, R. H. Organometallics 2003, 22, 1663. (b) Burling, S.; Douglas, S.; Mahon, M. F.; Nama, D.; Pregosin, P. S.; Whittlesey, M. K. Organometallics 2006, 25, 2642. (c) Ritleng, V.; Barth, C.; Brenner, E.; Milosevic, S.; Chetcuti, M. J. Organometallics 2008, 27, 4223. (d) Vélez, C. L., Markwick, P. R. L.; Holland, R. L.; DiPasquale, A. G.; Rheingold, A. L.; O'Connor, J. M. Organometallics 2010, 29, 6695. (e) Ragone, F.; Poater, A.; Cavallo, L. J. Am. Chem. Soc. 2010, 132, 4249. (f) Busetto, L; Cassani, M. C.; Femoni, C.; Mancinelli, M.; Mazzanti, A.; Mazzoni, R.; Solinas, G. Organometallics 2011, 30, 5258 .

(36) (a) Krug, C.; Hartwig, J. F. J. Am. Chem. Soc. 2004, 126, 2694. (b) Bontemps, S.; Gornitzka, H.; Bouhadir, G.; Miqueu, K.;Bourissou, D. Angew. Chem. Int. Ed. 2006, 45, 1611.

(37) (a) Selent, D.; Scharfenberg-Pfeiffer, D.; Reck, G.; Taube, R. J. Organomet. Chem. 1991, 415, 417. (b) Hahn, C.; Sieler, J.; Taube, R. Polyhedron 1998, 17, 1183. (c) Nguyen, D. H.; PérezTorrente, J. J.; Lomba, L.; Jiménez, M. V.; Lahoz, F. J.; Oro.L. A Dalton Trans. 2011, 40, 8429 .
(38) Rubio, M.; Suárez, A.; del Rio, E.; Galindo, A.; Álvarez, E.; Pizzano, A. Organometallics 2009, 28, 547

(39) Lee, S. I.; Park, S. Y.; Park, J. H.; Jung, I. G.; Choi, S. Y.; Chung, Y. K.; Lee, B. Y. J. Org. Chem. 2006, 71, 91.

(40) (a) Benati, L.; Capella, L.; Montevecchi, P. C.; Spagnolo P. J. Chem. Soc., Perkin Trans. 1 1995, 1035. (b) Kondoh, A.; Takami, K.; Yorimitsu H.; Oshima, K. J. Org. Chem. 2005, 70, 6468. (c) Hoyle, C. E.; Bowman, C. N. Angew. Chem. Int. Ed. Engl. 2010, 49,1540 .

(41) (a) Mueting, A. M.; Boyle, P.; Pignolet, L. H. Inorg Chem. 1984, 23, 44. (b) Osakada, K.; Hataya, K.; Yamamoto, T. Inorg. Chem. 1993, 32, 2360. (c) Osakada, K.; Yamamoto, T. Bull. Chem. Soc. Jpn. 1994, 67, 3271. (d) Cîrcu, V.; Fernandes, M. A.; Carlton, L. Polyhedron 2003, 22, 3293.

(42) (a) Evans, D. R.; Huang, M.; Senagish, W. M.; Chege, E. W.; Lam, Y.-F.; Fettinger, J. C.; Williams, T. N. Inorg. Chem. 2002 41, 2633. (b) Seino, H.; Yoshikawa, T.; Hidai, M.; Mizobe, Y. Dalton Trans. 2004, 3593. (c) Oster S. S.; Grochowski, M. R.; Lachicotte, R. J.; Brennessel, W. W.; Jones, W. D. Organometallics 2010 29, 4923. (d) Jiménez, M. V.; Lahoz, F. J.; Lukešová, L. Miranda, J. R.; Modrego, F. J. Nguyen, D. H.; Oro, L. A.; Pérez-Torrente, J. J. Chem Eur. J. 2011, 17, 8115.

(43) (a) Nemeh, S.; Jensen, C.; Binamira-Soriaga, E.; Kaska, W. C. Organometallics 1983, 2, 1442. (b) Kuznetsov, V. F.; Lough, A. J.; Gusev, D. G. Inorg. Chim. Acta 2006, 359, 2806. (c) Salem, H.; Shimon, L. J. W.; Leitus, G.; Weiner, L.; Milstein, D. Organometallics 2008, 27, 2293. (d) Findlater, M.; Cartwright-Sykes, A.; White, P.; Schauer, C. K.; Brookhart, M J. Am. Chem. Soc. 2011, 133, 12274.

(44) (a) Sandford, M. S.; Love, J. A.; Grubbs, R. H. Organometallics 2001, 20, 5314. (b) Urbina-Blanco, C. A.; Leitgeb, A.; Slugovc, C.; Bantreil, X.; Clavier, H.; Slawin, A. M. Z.; Nolan, S. P. Chem. Eur. J. 2011, 17, 5045

(45) (a) Rappert, T.; Nürnberg, O.; Mahr, N.; Wolf, J.; Werner, H. Organometallics 1992, 11, 4156. (b) Werner, H.; Baum, M.; Schneider, D.; Windmüller, B. Organometallics 1994, 13, 1089.

(46) (a) Schollhammer, P.; Cabon, N.; Capon, J.-F.; Pétillon, F. Y.; Talarmin, J.; Muir, K. W. Organometallics 2001, 20, 1230. (b) Ikada, T.; Mizobe, Y.; Hidai, M. Organometallics 2001, 20, 4441. (c) Kuniyasu, H.; Yamashita, F.; Terao, J.; Kambe, N. Angew. Chem Int. Ed. 2007, 46, 5929.

(47) (a) Sharpless, K. B.; Patrick, D. W.; Truesdale, L. K.; Biller, S. A. J. Am. Chem. Soc. 1975, 97, 2305. (b) Romão, C. C.; Kühn, F. E. Herrmann, W. A. Chem. Rev. 1997, 97, 3197. (c) Nishimura, T.; Onoue, T.; Ohe, K.; Uemura, S. J. Org. Chem. 1999, 64 6750. (d) Kamiya, I., Nishinaka, E.; Ogawa, A. J. Org. Chem. 2005, 70, 696. (e) Emmert, M. H.; Cook, A. K.; Xie, Y. J.; Sanford, M. S. Angew. Chem. Int. Ed. Engl. 2011, 50, 9409. (f) Ye, X.; Liu, G., Popp, B. V.; Stahl, S. S. J. Org. Chem. 2011, 76, 1031.

(48) (a) Cui, Q.; Musaev, D. G.; Morokuma, K. Organometallics 1998, 17, 1383. (b) Zheng, W.; Ariafard, A.; Lin, Z. Organometallics 2008, 27, 246. (b) Wang, M.; Cheng, L.; Wu, Z. Dalton Trans. 2008, 3879 .

(49) (a) SADABS: Area Detector Absorption Correction; Bruker-AXS, Madison, 1996. (b) Blessing, R. H. Acta Crystallogr. Sect A. 1995, 51, 33.

(50) SHELXL-97 Program for Crystal Structure Refinement, Sheldrick, G. M. University of Göttingen, Göttingen, 1997.

(51) Firsch, M. J.; et al. Gaussian 09, revision A.1; Gaussian, Inc. Wallingford, CT, 2004. The full reference is given in the supporting information.

(52) Lee, C.; Parr, R. G.; Yang, W. Phys. Rev. B 1988, 37, B785. Becke, A. D. J. Phys. Chem. 1993, 98, 64.

(53) Andrae, D.; Haeussermann, U.; Dolg, M.; Stoll, H.; Preuss, H. Theor. Chim. Acta 1990, 77, 123

(54) Morse, P. M.; Spencer, M. O.; Wilson, S. R.; Girolami, G. S. Organometallics 1994, 13, 1646. 
